\title{
Parenting and Externalizing Problem Behavior in Adolescence: \\ Combining the Strengths of Variable-Centered and Person-Centered Approaches
}

Date Submitted: 24/01/2018

Martijn Van Heel ${ }^{1}$, Wim Van Den Noortgate ${ }^{1}$, Patricia Bijttebier ${ }^{1}$, Hilde Colpin ${ }^{1}$, Luc Goossens $^{1}$, Karine Verschueren ${ }^{1}$, \& Karla Van Leeuwen ${ }^{1}$

${ }^{1}$ : Faculty of Psychology and Educational Sciences, KU Leuven, Belgium

Keywords: Externalizing problem behavior, Adolescence, Parenting, Longitudinal, Multi-informant

Author Note

Correspondence concerning this article should be addressed to Martijn Van Heel, Faculty of

Psychology and Educational Sciences, KU Leuven, Tiensestraat 102 - box 3722, 3000

Leuven, Belgium.

E-mail: martijn.vanheel@kuleuven.be

(C)American Psychological Association, 2018. This paper is not the copy of record and may not exactly replicate the authoritative document published in the APA journal. Please do not copy or cite without author's permission. The final article is available, upon publication, via its DOI: $10.1037 / \mathrm{dev} 0000644$ 


\begin{abstract}
Previous studies often assumed that parenting practices are similar across families. This assumption is difficult to hold, especially throughout adolescence, a period of major change for both adolescents and their parents. By combining a person-centered and a variable-centered approach, the present study adds to the literature by identifying trajectory classes in parenting behaviors and assessing their associations with externalizing problem behavior. The study aimed (a) to examine the existence of subgroups with different trajectories for five parenting dimensions (i.e., Support, Proactive Control, Punitive Control, Harsh Punitive Control, Psychological Control) in mothers and fathers separately, and (b) to assess whether membership of a subgroup is associated with the development of rule-breaking and aggressive behavior, respectively. The current study used four waves of data, with adolescents' age ranging from 12 to 18 years. Mothers $(N=747)$ and fathers $(N=645)$ reported on their own parenting behavior, whereas adolescent $(N=1,116)$ reported on externalizing problem behavior. Latent Class Growth Analyses per parenting dimension showed that trajectory classes could be distinguished for support, proactive, punitive, and psychological control, but not harsh punitive control, and this for both mother and father. Conditional growth models per parenting dimension and per parent did not show different trajectories for aggressive and rule-breaking behavior across adolescence for the distinct parenting trajectories. However, analyses indicated that depending on the parenting trajectory, there was a difference in initial (age 12) levels of problem behavior. Suggestions for additional research on longitudinal heterogeneity of parenting among mothers and fathers of adolescents are outlined.
\end{abstract}




\section{Introduction}

Parenting is a complex concept that can be framed from various theoretical perspectives (Baumrind, 1971; Darling \& Steinberg, 1993). There is, however, consensus on the main purpose of parenting, namely to socialize the child/adolescent, that is, to help children and adolescents to develop social, emotional, and cognitive skills needed to function in a social environment (Grusec \& Davidov, 2010). Inadequate parenting can lead to child and adolescent maladaptive functioning such as exhibiting externalizing problem behavior (Eichelsheim et al., 2010; Galambos, Barker, \& Almeida, 2003; Hanisch, Hautmann, Plück, Eichelberger, \& Döpfner, 2014). Externalizing problem behavior refers to behavior that is directed outwards and victimizes others (e.g., aggression and delinquency) (Achenbach, 1991) and can be split up into two subtypes: aggressive behavior (e.g., hitting someone) and rulebreaking behavior (e.g., breaking the evening curfew) (Achenbach, 1991). A study by Reitz et al. (2005) showed that approximately $60 \%$ of the adolescents exhibit some kind of problem behavior during adolescence. Furthermore, boys appear to exhibit higher levels externalizing problem behavior and their increase in such problem behavior is larger across adolescence (Hicks et al., 2007 Given the detrimental effects of these problem behaviors for the environment and adolescent psychosocial functioning, it is worthwhile to study this life stage to be able formulate suggestions for prevention and intervention.

The associations between problem behavior and parenting are well established in adolescence (De Haan et al., 2012) as well as the association between problem behavior in adolescence and problem behavior in adulthood (Reef, Diamantopoulou, van Meurs, Verhulst, \& van der Ende, 2010). Several parenting dimensions are associated with externalizing problem behavior in adolescence. Some have been linked to higher levels of problem behavior, such as negative parenting (i.e., lax and overreactive discipline and hostile parenting practices; Hanisch et al., 2014) and psychological control (Pettit, Bates, \& Dodge, 1997), whereas other dimensions are linked to less problem behavior, such as parental monitoring (Denham et al., 2000) or parental support (Tuggle, Kerpelman, \& Pittman, 2014). Previous studies in adolescence have established that different aspects of parenting each have unique relationships with externalizing problem behavior (e.g. Hanisch et al., 2014; Lansford et al., 2011; Mabbe, Soenens, Vansteenkiste, \& Van Leeuwen, 2016; Pettit, Bates, \& Dodge, 1997; Stormshak, Bierman, McMahon, \& Lengua, 2000). Furthermore, it is important to assess both maternal and paternal parenting since 
previous studies have indicated that both uniquely contribute to the adolescent's development (Hoeve Dubas, Gerris, van der Laan, \& Smeenk, 2011; Jeynes, 2016).

In the aforementioned studies, which used a variable-centered approach to study parenting, conclusions were made across families, and the authors assumed that the covariation of parenting and problem behavior is the same for all families (Mandara, 2003). However, it is unlikely that associations between parenting and child outcomes will be similar for all families in the population. A personcentered approach takes into account that there might be subgroups of individuals and that individuals within such a group or category are more alike than individuals across groups (Jung \& Wickrama, 2008). Identifying subgroups of parents, showing different trajectories in their use of parenting practices, might reveal distinct relationships with child externalizing behavior. For example, it could be that adolescents with problem behavior have parents who are members of pronounced parenting trajectories (e.g. consistently low positive or extremely inadequate parenting, or unstable, turbulent parenting trajectories), whereas adolescents without problem behavior have parents who are assigned to moderate parenting trajectories. To our knowledge, only two studies (Luyckx et al., 2011, Okado \& Haskett, 2015) combined a person-centered and variable-centered approach to report on the relation between parenting trajectories and externalizing problem behavior, adopting different but complementary approaches.

Okado and Haskett (2015) used observational data on parenting practices and examined two broad parenting dimensions: positive and negative parenting. The former refers to a warm and responsive relationship between parent and child, whereas the latter refers to a detached and hostile relationship. The authors performed two Latent Class Growth Analyses (LCGA) (i.e., one for positive and one for negative parenting) on a small sample of abusive parents of children $(N=43)$ and identified two subpopulations per parenting dimension that differed in developmental trajectory across (three years of) early childhood. Their results showed that the children from the "warmer" trajectory class, in which parents exhibited consistently high levels of positive parenting and low levels of negative parenting, showed better behavioral adjustment later on in childhood.

Luyckx et al. (2011) investigated a more detailed parenting model comprising positive parenting, monitoring, and inconsistent discipline using questionnaire data. The positive parenting dimension resembles positive parenting in the study by Okado and Haskett (2015). Monitoring was 
referred to as supervising children's behavior within reasonable boundaries by creating an organized and predictable environment, whereas inconsistent discipline referred to the act of being inconsistent with said boundaries and creating an unpredictable environment (Luyckx et al., 2011). The latter two dimensions are a positive and a negative indicator, respectively, of behavioral regulation. The authors investigated the heterogeneity in trajectories of parenting practices throughout adolescence (ages 12-18) in a large sample of children $(\mathrm{N}=1,049)$ and applied LCGA to these dimensions simultaneously. In other words, they included all the parenting dimensions in a single LCGA. The results revealed four trajectory classes for parenting in concordance with the theoretical framework of Steinberg (2001). This theory conceptualizes four parenting styles (i.e., authoritative, authoritarian, indulgent, and uninvolved parenting) on the basis of two main parenting dimensions, that is, positive parenting and behavioral regulation. Luyckx et al. (2011) showed that the "authoritative" trajectory class (i.e., consistently high parental support combined with high behavioral regulation; cfr. Baumrind, 1967) was the most beneficial for the adolescent in the long term. More specifically, membership of this trajectory class was associated with less adolescent alcohol and cigarette use, fewer internalizing problems, and fewer externalizing problems. The approaches of Okado and Haskett (2015) and of Luyckx et al. (2011) provided very useful information but also indicated a gap in the literature. No study has assessed trajectory classes within a large sample, starting from a more comprehensive parenting model and taking into account both maternal and paternal parenting.

In the current study, we addressed this gap, by examining the associations between trajectories of externalizing problem behavior across adolescence with membership to subpopulations in maternal and paternal parenting (i.e., fitting separate LCGA per parenting dimension cfr. Okado \& Haskett, 2015), starting from a comprehensive five-factor parenting model (Janssens et al., 2015) consisting of parenting dimensions that were found to be related to externalizing behavior (cfr. Luyckx et al., 2011). The personcentered approach offers the added value of distinguishing groups of individuals in their use of certain parenting practices. In the current study the person-centered approach is particularly interesting since it concerns distinguishing groups across a period where parents have to adapt their parenting practices to the maturing adolescent, which goes beyond assessing static representations of parenting behavior.

\section{A Five-Factor Model of Parenting and its Relation With Externalizing Problem Behavior}


Janssens and colleagues (2015) identified a model of parenting by performing confirmatory factor analyses on questionnaire data from mothers, fathers, and adolescents. A five-factor solution emerged, including parental support, proactive control, punitive (non-physical) control, harsh punitive (physical) control, and psychological control. In the following section, we discuss each of these five dimensions and their link with externalizing problem behavior in early (age 12-14), middle (age 15-16) and/or late adolescence (age 17-18).

Parental support is an umbrella term which comprises, among other things, parental involvement, acceptance, emotional availability, and responsivity. In general, it shows negative associations with child/adolescent externalizing problem behavior (Hanisch et al., 2014; Laible, Carlo, \& Raffaelli, 2000). Results from previous studies also suggested a positive association between parental support, on the one hand, and social development (e.g., Barber, Stolz, \& Olsen, 2005), academic performance (Tang \& Davis-Kean, 2015) and morality (Bronstein, Fox, Kamon, \& Knolls, 2007), on the other. Proactive control involves the use of a structured environment to anticipate and prevent possible undesirable child or adolescent behavior. Such an environment can be created through rule setting and parental monitoring (Socolar, 1997). Given the increasing number of activities and relationships outside the family context, it can be hypothesized that proactive control gains importance in adolescence. Parents will not always be present to shape the behavior of their son or daughter, and thus preventive rule setting (partially) takes over this role (Pettit et al., 1997). This parenting dimension has been found to correlate negatively with externalizing problem behavior (Galambos et al., 2003; Gray \& Steinberg, 1999; Pettit et al., 1997). Punitive (non-physical) control is characterized by non-physical punishment (e.g., giving chores or setting an earlier curfew) and is considered to be an effective way to induce immediate compliance (Baumrind, 1996). Despite this efficacy, it is associated with more externalizing problem behaviors in the long term (Brenner \& Fox, 1998; Stormshak, Bierman, McMahon, \& Lengua, 2000). Harsh (physical) punitive control refers to the use of corporal punishment (e.g., slapping following unwanted behavior). Young people who suffered physical punishment throughout early and middle adolescence show more externalizing problem behavior (Bender et al., 2007; Lansford et al., 2011). A study by Wang and Kenny (2014) suggested a vicious cycle between physical punishment and externalizing problem behavior. Children's externalizing problem behavior 
triggers physical punishment from the parents, which in turn, elicits more problem behavior. This interplay can escalate with devastating effects for adolescent development. Psychological control includes manipulating thoughts, feelings, and emotions (Barber, 1996). This intrusive parenting practice uses children's desire not to disappoint their parents, to attain behavioral compliance (Assor, Roth, \& Deci, 2004). Barber, Olsen, and Shagle (1994) found an association between psychological control and internalizing problem behavior. Later research also suggested an association with externalizing problem behavior (Ahmad, Vansteenkiste, \& Soenens, 2013; Mabbe et al., 2016). This overview of studies shows that every dimension of the five-factor parenting model is associated with externalizing problem behavior. Therefore, it is useful to assess trajectory classes in each of the five dimensions.

\section{The Present Study}

The aim of the present study was twofold. First, we examined whether subgroups with distinctive trajectories across adolescence could be identified for each of the five parenting dimensions that were established by Janssens et al. (2015). These dimensions were assessed at four time points, which leads to more dynamic measures of the parenting behaviors. More specifically, the trajectories covered adolescent age from 12 to 18 years. It is strategically important to investigate this age range, which covers early, middle, and late adolescence, because adolescents undergo great developmental changes during this period of life. Parenting trajectories were assessed for mothers and fathers separately, in order to examine whether the number and the shape of the trajectories are different for mothers and fathers. We expected to find such differences, given that the literature has revealed differences in maternal and paternal parenting practices at least in samples with younger children (Videon, 2005; Winsler, Madigan, \& Aquilino, 2005).

Second, we assessed whether membership to one of the trajectory classes or adolescent gender was associated with the initial levels and changes of externalizing problem behavior. We expected that parents who are member of trajectory groups showing high levels of parental support (Stice, Barrera, \& Chassin, 1993) or proactive control (Galambos, Barker, \& Almeida, 2003) would have adolescents with lower levels of rule breaking and aggressive behavior, compared to parents who are members of trajectories with low levels of support or proactive control. Parents from trajectory classes showing high levels of punitive (Larzelere, Cox, \& Smith, 2010), harsh punitive (Gershoff \& Grogan-Kaylor, 2016), 
or psychological control (Pettit, Laird, Dodge, Bates, \& Criss, 2001) were expected to have adolescents showing higher levels of both rule breaking and aggressive behavior, compared to parents from trajectory classes characterized by moderate or low levels of punitive, harsh punitive or psychological control. Because the literature indicates that there are differences in externalizing problem behavior between boys and girls (Bongers, Koot, van der Ende, \& Verhulst, 2004), gender was included in all analyses. This study will add to the literature by providing a more dynamic and differentiated image of parenting behaviors related to subtypes of externalizing behavior, by identifying trajectories over time for both mothers and fathers, instead of the static and broad image that is usually derived from questionnaire data at a single time point from a single informant.

\section{Methods}

\section{Participants and Procedure}

Data were collected within the STRATEGIES project (i.e., Studying Transactions in Adolescence: Testing Genes in Interaction With Environments). Permission for the STRATEGIES project was obtained from the institutional review board of the Faculty of Medicine at the University of Leuven (ML7972). For four years, this longitudinal study annually examined adolescents and their parents in Flanders, the Dutch-speaking part of Belgium. Adolescents and their parents were selected through a random multistage sampling approach. Twenty Flemish secondary schools were randomly selected and invited to take part in the study. Of the nine schools who indicated to be willing to participate, 121 classes in Grades 7 to 9 were randomly selected. Stratification at the class level was used to attain an adequate reflection of the population concerning the distribution of students from the general, technical, and vocational tracks. Within these classes, 2,254 students and their parents were invited to participate. From these 2.254 students, 1,116 students responded and agreed to participate in this study, whereas the remaining 1,138 did not respond to our invitation. These 1,116 students also received an informed consent to pass on to their mother and father. Adolescents were offered 5 euros (per wave) and a raffle of a larger prize, e.g. i-Pod) for their participation, whereas parents did not receive any incentive. The final sample at Wave 1 comprised 1,116 adolescents in three cohorts (grade 7,8 , and 9) $\left(M_{\mathrm{age}}=13.70, S D=0.93,51 \%\right.$ boys $), 839$ mothers $\left(M_{\mathrm{age}}=43.54, S D=4.45\right)$ and 717 fathers 
$\left(M_{\text {age }}=45.45, S D=4.69\right)$. In Wave 1,710 adolescents had their both parents reporting, whereas $129(7)$ had only their mother (father) reporting. Compared to Wave 1, the retention rate in Wave 2 was $89 \%$ for adolescents, $75 \%$ for mothers, and $73 \%$ for fathers (both parents : 495; only mother: 135 ; only father: 28). In Wave 3, the retention rate remained $79 \%$ for adolescents, $66 \%$ for mothers and $63 \%$ for fathers (both parents : 427; only mother: 105; only father: 19). In Wave 4, the retention rates were $45 \%, 38 \%$, and $37 \%$, respectively $(N$ adolescents $=499, N$ mothers $=318, N$ fathers $=268)$ (both parents: 255 ; only mother: 50; only father: 7). The drop in retention rates in Wave 4 is remarkably stronger. This may be caused by the oldest cohort graduating from high school in the transition from Wave 3 to Wave 4, which made data collection more difficult. Family characteristics were representative for the general population $\chi^{2}(2)=2.78, p=.25$, with $82 \%$ two-parent families, $7 \%$ single-parent families, and $11 \%$ percent blended families ([Blinded]; King Baudouin Foundation, 2008). The educational level (EDU) and employment activity level (EMP) of parents differed for both mothers (EDU: $\chi^{2}((3)=30.34, p=$ $<.001$; EMP: $\chi^{2}((1)=15.87, p=<.001)$ and fathers (EDU: $\chi^{2}(3)=34.19, p=.00$; ACT: $\chi^{2}(1)=15.13$, $p=<.001)$ with bachelor degrees and active employees being slightly overrepresented ([Blinded]; Research Department of the Flemish Government, 2010, 2011). Despite this small deviation, it can be concluded that participants represent all categories for socioeconomic status.

Researchers visited the school and presented the questionnaire to the adolescents. In concert with the school, adolescents were provided two hours to fill out the questionnaire. In case they did not finish the questionnaire within the provided time, they were allowed to finish the questionnaire at home and hand it in later using specially designated boxes. Adolescents who left the school or graduated were contacted through e-mail and received an online version of the questionnaire. Parents could either fill out their questionnaires online or on paper. The latter was provided through the adolescents and could also be handed in using the designated boxes.

The [Blinded] project used an accelerated longitudinal design. This design allows researchers to cover a larger age span, compared to a classical longitudinal design, during a shorter time span. In every wave, an age range is covered, which will overlap with the age range of the next wave. At each wave, the same sample was invited to participate in the study. Across the four annual waves, the ages ranged from 12 to 18 years old. Given the accelerated longitudinal design, there is dependency between 
the data points of one adolescent and (structurally) missing data points (e.g., a child that was first assessed in grade 9 cannot have data at age 12).

\section{Measures}

\section{Parenting Behavior}

Parenting was rated by mothers and fathers using a total of 64 items from 9 subscales from multiple questionnaires. These questionnaires and their respective subscales were selected in the [Blinded] based on theoretical relevance, adequate psychometric properties, and use in previous parenting research (Janssens et al., 2015). A confirmatory factor analysis (CFA) on these questionnaires resulted in the five-factor model of parenting dimensions described in the Introduction (Janssens et al., 2015). Janssens et al. (2015) showed that this five factor model was to be preferred over a three or four factor model, which provides support for the value of the different parenting dimensions. According to Cohen's criteria for effect sizes (Cohen, 1992), correlations between parenting dimensions were small to medium. Furthermore, Van Heel et al. (2017) established at least partial scalar measurement invariance across adolescence and across informants for this five factor parenting model on the same dataset, hence, these constructs can be validly compared. This shows that the five factor model is robust across adolescence and for different informants (i.e., mothers, fathers, and adolescents).

The dimension Parental Support (Cronbach's $\alpha$ at W1 $=.89, \mathrm{~W} 2=.90, \mathrm{~W} 3=0.90, \mathrm{~W} 4=.91$, (mother) and $\mathrm{W} 1=.93, \mathrm{~W} 2=.93, \mathrm{~W} 3=.93, \mathrm{~W} 4=.93$ (father) $)$ was measured using three parenting measures. The first one was the Positive Parenting subscale (8 items, e.g., "If my son or daughter wants to tell something, I take my time for listening to him/her") from the Parental Behavior Scale- Short Form (PBS-S; Van Leeuwen et al., 2015). The second one was the Responsivity subscale (7 items, e.g., "I can make my son or daughter feel better when he or she is feeling upset) from the Louvain Adolescent Perceived Parenting Scale (LAPPS; Delhaye et al., 2012). This instrument is an adaptation of a subscale from the Child Report of Parental Behavior Inventory (CRPBI; Schludermann \& Schludermann, 1988). The third and final measure was the Autonomy Support scale (8 items, e.g., "I take into account my son's or daughter's opinion on affairs that concern him or her") and was based on the Perceptions of 
Parents Scale (POPS; Grolnick, Ryan, \& Deci, 1991) and the Research Assessment Package for Schools (RAPS; Institute for Research and Reform in Education, 1998).

The dimension Proactive Control (Cronbach's $\alpha$ at $\mathrm{W} 1=.85, \mathrm{~W} 2=.83, \mathrm{~W} 3=.84, \mathrm{~W} 4=.86$, (mother) and $\mathrm{W} 1=.85, \mathrm{~W} 2=.85, \mathrm{~W} 3=.85, \mathrm{~W} 4=.87$ (father) ) was assessed using two measures, that is, the subscales Setting Parental Expectations for Behavior (6 items, e.g., "I expect my son or daughter to behave in a certain manner) and Parental Monitoring of Behavior (6 items, e.g., "I remind my son or daughter of the rules I made"). These subscales were selected from the Parental Regulation Scale (PRSYSR; Barber, 2002), which was translated in Dutch by Soenens, Vansteenkiste, Luyckx, and Goossens (2006).

The dimension Punitive Control was assessed using the Punishment subscale (4 items, e.g. "If my son or daughter does something he or she was not supposed to, I punish him or her"; Cronbach's $\alpha$ at $\mathrm{W} 1=.88, \mathrm{~W} 2=.89, \mathrm{~W} 3=.89, \mathrm{~W} 4=.92($ mother $)$ and $\mathrm{W} 1=.88, \mathrm{~W} 2=.88, \mathrm{~W} 3=.88, \mathrm{~W} 4=.91$ (father) from the Parental Behavior Scale - Short Form (PBS-S; Van Leeuwen et al., 2015).

The dimension Harsh Punitive Control was assessed using the subscale Harsh Punishment (5 items, e.g., "I hit my son or daughter in the face when he or she misbehaves"; Cronbach's $\alpha$ at W1 = $.78, \mathrm{~W} 2=.57, \mathrm{~W} 3=.39, \mathrm{~W} 4=.56,($ mother$)$ and $\mathrm{W} 1=.80, \mathrm{~W} 2=.73, \mathrm{~W} 3=.68, \mathrm{~W} 4=.54$ (father) $)$ from the Parental Behavior Scale - Short Form (PBS-S; Van Leeuwen et al., 2015).

The dimension Psychological Control (Cronbach's $\alpha$ at W1 $=.84, \mathrm{~W} 2=.84, \mathrm{~W} 3=.84, \mathrm{~W} 4=$ .84 , (mother) and $\mathrm{W} 1=.83, \mathrm{~W} 2=.84, \mathrm{~W} 3=.86, \mathrm{~W} 4=.88$ (father)) was assessed using two subscales. The subscale Psychological Control (8 items, e.g., "I do not talk to my son or daughter when he or she disappointed me until he or she pleases me again") was taken from the translated version of Barber's Psychological Control Scale (Barber, 1996; Soenens et al., 2006). One additional item for this subscale was based on a study by Soenens, Sierens, Vansteenkiste, Dochy, and Goossens (2012). The subscale Hostility (6 items, e.g., "I yell at my son or daughter when he or she misbehaves") was based on the Verbal Hostility Scale (Nelson \& Crick, 2002), which was developed to assess intrusive parenting alongside corporal punishment.

All 64 items were rated by mothers and fathers on a 5-point scale ranging from $1=($ almost $)$ never to $5=($ almost $)$ always. Mothers and fathers reported on their own parenting behavior. 


\section{Adolescent Problem Behavior}

Adolescents completed the externalizing subscales of the Youth Self Report (YSR; Achenbach 1991). The second-order scale Externalizing Problem Behavior (31 items, Cronbach's $\alpha$ at W1 $=.82$, $\mathrm{W} 2=.84, \mathrm{~W} 3=.82, \mathrm{~W} 4=.82)$ was decomposed into two subscales. Specifically, the two subscale were Aggressive behavior which physical aggression, as well as disruptive and non-compliant behaviors (17 items, e.g., "I destroy my own belongings"; Cronbach's $\alpha$ at W1 $=.78, \mathrm{~W} 2=.80, \mathrm{~W} 3=.78, \mathrm{~W} 4=.77$ ) and Rule-breaking behavior (14 items, e.g. "I skip classes or I play truant”; Cronbach's $\alpha$ at W1 $=.58$, $\mathrm{W} 2=.66, \mathrm{~W} 3=.63, \mathrm{~W} 4=.62) . \mathrm{A}$ three-point rating scale was used, ranging from $0($ not true $)$ to 2 (very true or often true). For both subscales, the mean score was computed. Higher scores indicated more externalizing problem behavior.

\section{Analysis Strategy}

\section{Attrition Analysis}

To check for systematic dropout, independent samples t-tests were used to assess whether there was a significant difference in externalizing problem behavior and parenting (both maternal and paternal) at Wave $\mathrm{k}$ between adolescents that dropped out after this wave and adolescents who still participated at Wave $\mathrm{k}+1$.

\section{Descriptive Statistics}

Mean scores and variances of maternal and paternal parenting as well as externalizing problem behavior were calculated per time point. Furthermore, correlations between paternal and maternal parenting dimensions were computed per time point.

\section{Latent Class Growth Analysis}

To identify classes with distinct longitudinal trajectories for each parenting dimension, Latent Class Growth Analyses (LCGA) (Jung \& Wickrama, 2008) were used. This special form of Growth Mixture Modeling (GMM) assumes that the individual growth trajectories are homogeneous within each trajectory class. In the search for an appropriate number of trajectory classes, multiple criteria were used, following Jung and Wickrama (2008). This approach enabled us to make a grounded decision in situations where a single criterion could not differentiate between two potential models. To arrive at a structured decision-making process, the criteria were considered in a specific order. 
First, in order to keep the classes practically relevant and the model stable, the size of the smallest class should not fall below $1 \%$ of the total population (Jung \& Wickrama, 2008). In other words, only the models in which the smallest class count was equal to or larger than $1 \%$ of the total sample were considered. Second, the Bootstrapped Likelihood Ratio Test (BLRT), which is the best performing fit index in indicating a suitable number of classes (Nylund, Asparouhov, \& Muthen, 2007), was included to assess model fit. The BLRT compares the improvement in fit from a model with $k-l$ classes with a growth model with $k$ classes. In the present study, the $\alpha$-level for this statistic was set at .05 . A significant $(<.05) p$-value indicates that a model with $k$ classes yields a better fit than a model with $k$ - 1 classes. However, the BLRT involves a large computational burden and therefore is not requested by default. To deal with this issue, we followed Nylund (2007), who suggested to use the Lo, Mendell, and Rubin likelihood ratio test (LMR; Lo, Mendell, \& Rubin, 2001) to pre-select a number of models, which can be re-analyzed with requesting the BLRT. Jung and Wickrama (2008) set an $\alpha$-level of .05 for the LMR. However, because we considered our analysis to be exploratory, the present study used an $\alpha-$ level of .10. This value was selected to prevent excluding models prematurely. In other words, model fit was first assessed using LMR $(\alpha=.10)$. If the models showed significance for LMR, the analyses were run again by requesting the BLRT $(\alpha=.05)$. If the BLRT was also significant, model fit was considered to be good. Third, when there were still multiple eligible models, the model with the lowest Sample Size adjusted Bayesian Information Criterion (SS-BIC) was selected. Nylund (2007) has determined that SS-BIC is the second best performing fit index after the BLRT referred to earlier on. Next, entropy was used to estimate classification accuracy. This index is based on posterior probabilities of classification and ranges from 0 (i.e., everybody has the same probability of being classified in a certain class) to 1 (i.e., each individual has been classified into a certain class with a posterior probability of 1) (Feldman, Masyn, \& Conger, 2009). There is no specific cut-off score for entropy, but extremely low values indicate that classification accuracy is not adequate for a given model.

\section{Growth Models}

Growth models were fitted to assess the predictive value of trajectory classes based on the parenting dimensions reported by mother and father separately, for the growth parameters of rulebreaking behavior and aggressive behavior, reported by the adolescent. These analyses built on the 
trajectory classes per parenting dimension and per parent identified in the LCGA. In all, there were 20 possible growth models (i.e., 2 (variants of externalizing problem behavior) x 2 (informants) x 5 (parenting dimensions)). As suggested by Chen et al. (2008), three model fit indices were used to assess model fit of the growth models, that is, the Comparative Fit Index (CFI), the Root Mean Square Error of Approximation (RMSEA), and the Standardized Root Mean Squared Residual Error (SRMR). Concerning the CFI, a value above .90 is deemed an acceptable fit, but a value above .95 is preferred. Concerning the RMSEA, a value below .08 indicates an acceptable fit, but a value below .05 is preferred. Concerning, the SRMR, a value below .08 is indicative of a good model fit (Browne \& Cudeck, 1992; Hu \& Bentler, 1999).

First, an unconditional growth model was fitted for rule-breaking behavior and aggressive behavior separately. In order to assess which growth parameters are needed to adequately represent the trajectory of both types of externalizing problem behavior three models were compared to each other (i.e., Model 1: intercept; Model 2: intercept + linear trend; Model 3: intercept + linear trend + quadratic trend). We based our decision on both overall better model fit and statistical significance of the growth parameters within a model in order to ensure that growth parameters are meaningful for subsequent analyses. To account for dependency between time points within one adolescent, the present paper used a Generalized Estimating Equation (GEE) approach (Hubbard et al., 2010), which corrects the standard errors accordingly. In a next step, gender and the trajectory classes of a parenting dimension were included. In these analyses, the largest trajectory class was used as the reference category. For each of the other trajectory classes of a parenting dimension, a dummy variable was created with ' 0 ' indicating that an individual was not a member of the trajectory class and ' 1 ' indicating that he or she was a member. These dummy variables indicating trajectory class membership were considered as timeinvariant categorical predictor variables in the growth models.

Normality tests per wave (i.e., Kolmogorov-Smirnov and Shapiro-Wilk) assessed whether the distribution of residuals of both rule-breaking behavior and aggressive behavior approximated a normal distribution. These tests indicated that this was not the case (See Table S1). This non-normality was handled in all subsequent analyses by using a robust estimator (robust maximum likelihood) (Finney \& DiStefano, 2008). Given the large number of associations to be tested within a single growth model and 
the related elevated chance to make Type-I errors, a Bonferroni correction (Armstrong, 2014) was applied in the conditional growth models. More specifically, the $\alpha$-level is adjusted for the number of statistical tests, which in the present study resulted in an $\alpha$-level of $(.05 / 13=) .004$. The analyses were conducted in MPlus Version 7 (Muthén \& Muthén, 2012). In MPlus missing data were handled using Full Information Maximum Likelihood (FIML) and robust maximum likelihood (MLR) was used as estimator.

\section{Results}

\section{Attrition Analysis}

The results of the attrition analysis showed that missing data were not Missing Completely At Random (MCAR), however, Sterne et al. (2009) suggest that the Missing At Random (MAR) assumption is plausible when a wide array of covariates that predict the attrition is available. The longitudinal dataset used in the present study comprises information on numerous demographic variables (e.g., ethnicity, gender, family situation, SES) and as such the assumption of MAR is deemed plausible. Assuming MAR, Full Information Maximum Likelihood (FIML) corrects the estimation of the individual growth parameters in growth curve analysis for systematic attrition (Assendorpf, van de Schoot, Denissen, \& Hutteman, 2014). Detailed results are presented in Table S2.

\section{Descriptive Statistics}

Descriptive statistics of the five parenting dimensions as reported by mothers and fathers and of rule-breaking and aggressive behavior as reported by adolescents are presented in Table 1. Correlational analysis per wave of parenting dimensions as reported by mothers and fathers are includes in the Supplemental Materials (Tables S3a through S3f).

\section{Determining the Number of Trajectory Classes}

In order to establish a meaningful number of trajectory classes, the aforementioned fit indices were obtained (when available) for one up to five trajectory classes per dimension. In these analyses the first five time points were included (i.e., ages 12 to 17), because inclusion of the sixth time point led to convergence issues. More specifically, there were too few observations to initiate FIML, and thus also estimation, due to drop out as well as structural missingness. The fit indices are presented in Table 2a 
for mothers and Table $2 \mathrm{~b}$ for fathers. The trajectory classes obtained were interpreted based on the size of the intercept, as well as the presence of a linear and/or quadratic trend. The estimates and their $p$ values of all the growth parameters are included in the (See Table S4).

A trajectory class was labelled "low" when the intercept was equal or lower than 2, "moderate" when the intercept was a value between 2 and 4, and "high" when the intercept was higher than or equal to 4. If multiple trajectory classes were in one of these three categories, additional labels were used to indicate their relative position (e.g., labels "moderately high" versus "moderately low" were used to indicate their relative position within the moderate range).

The linear trend and quadratic trend were identified based on visual inspection of the plots. This decision was made due to the fact that labels based upon statistical significance are not always useful and/or relevant, and thus, make interpretations more difficult. A linear trend was considered to be increasing (decreasing) when there was at least a 0.5 difference between Time point 1 and Time point 5. A quadratic trend was considered to be U-shaped (inverse U-shaped) when there was an initial decrease of at least 0.5 , followed by an increase of at least 0.5 .

Mothers. Three meaningful trajectory classes were identified for the dimensions support (i.e., very high-stable, moderate-stable, and high-stable; entropy = .74) and proactive control (i.e., high-stable, moderate-stable, very high-stable; entropy $=.64$ ), whereas for punitive (i.e., low-stable, high-decreasing, moderate high-decreasing, moderate low-decreasing; entropy $=.60)$ and psychological control (i.e., lowstable, moderate high-decreasing, moderate low-stable, moderate-stable; entropy $=.70$ ) four trajectory classes could be distinguished. The entropy values indicated that the solution for maternal support had the greatest classification accuracy. The trajectory classes for these four parenting dimensions are presented in Figures 1a to 1d, respectively. For harsh punitive control, fit indices indicated that no meaningful trajectory classes, could be distinguished, which implied that the average trajectory was the most adequate representation of the whole sample. Consequently, harsh punitive control was not included in subsequent analyses.

Fathers. We distinguished two meaningful trajectory classes for paternal support (i.e., high stable, moderate-increasing; entropy $=.60$ ), whereas four meaningful trajectory classes were distinguished for proactive control (i.e., moderate-increasing, very high-stable, high-stable, low- 
increasing-inverted U-shape; entropy $=.75$ ), punitive control (i.e., low-stable, moderate-decreasing, moderate-increasing-U-shape, high-decreasing; entropy $=.60$ ) and psychological control (i.e., lowstable, moderate low-stable, moderate high-U-shape, moderate high-inverted U-shape; entropy $=.62$ ). The entropy values for the classification of support, punitive control, and psychological control were lower than in mother reports, but were still clearly closer to 1 than to 0 . The highest entropy value, also higher than the maternal counterpart, was found for paternal proactive control. The trajectory classes for these four parenting dimensions are presented in Figures 2a to 2d, respectively. In line with our results for the mother reports, no meaningful subclasses could be established for harsh punitive control. Note that the total number of adolescents that was allocated to the trajectory classes per parenting dimension can differ due to different patterns of missing data.

\section{Growth Models}

For both aggressive and rule-breaking behavior the unconditional growth model including an intercept, linear trend and quadratic trend showed the best overall model fit (See Table 3). However the quadratic term was non-significant $(p=.82)$ for aggressive behavior, but significant $(p=.002)$ for rulebreaking behavior. Thus, rule-breaking behavior was represented by a growth model including an intercept, linear trend, and quadratic trend, whereas aggressive behavior was represented by a growth model that included an intercept and linear trend.

Next, 16 (i.e., 4 parenting dimensions $\mathrm{x} 2$ parents $\mathrm{x} 2$ variants of externalizing problem behavior) conditional growth models were fitted, which each comprised both gender and the dummy variables representing trajectory group membership for a single parenting dimension reported by a single parent. These conditional growth models all showed good model fit (CFI> .95, RMSEA <.06, SRMR <.08). A detailed overview of the model fit indices per conditional growth model is included in the Supplemental Materials (See Table S5a and Table S5b for maternal parenting and Table S6a and S6b for paternal parenting). Note that there was no conditional growth model for harsh punitive control, given the fact that no meaningful trajectory classes could be distinguished for this parenting dimension.

The proportions of explained variance for each conditional growth model are presented in Table 4a through $4 \mathrm{~d}$. Concerning maternal trajectory classes, the $R^{2}$ 's indicated that the trajectory classes of each parenting dimension explained a significant $(p<.05)$ proportion of the variance in the intercept, 
but not the linear trend or quadratic trend, for both aggressive behavior and rule-breaking behavior. Approximately the same results were found concerning paternal trajectory classes. However, the proportion of the variance explained by the trajectory classes of support $(p=.059)$ and proactive control $(p=.068)$ was borderline significant.

Aggressive behavior. The results for the trajectory classes of support are presented in Table 4a, for proactive control in Table $4 \mathrm{~b}$, for punitive control in Table $4 \mathrm{c}$ and for psychological control in Table 4d. In general, there were no significant associations found concerning to gender. There does not seem to be a difference between boys and girls in the levels of aggressive behavior. In analyses with maternal parenting trajectory groups as predictors, the intercept of the growth model of aggressive behavior was higher in the 'moderate-stable' trajectory class of support, compared to the reference category. Likewise, the 'high-stable' support trajectory class also showed more aggressive behavior at age 12. It should be noted that the 'high-stable' group showed lower levels of support than the reference group, which is 'very high-stable'. In other words, the lower the levels of support, the higher the levels of aggressive behavior at age 12. This pattern of findings indicated that a relative lack of maternal support is related to more initial aggressive behavior, despite the fact that the lower levels are still in the "high" and "moderate" range. The trajectory classes of proactive control did not differ in intercept or growth for aggressive behavior. Concerning punitive control, the 'low-stable' trajectory class showed less initial aggressive behavior, compared to the trajectory class with high levels of punitive control. Finally, the 'low-stable' trajectory class for psychological control was positively associated with the intercept of aggressive behavior in comparison to the reference trajectory class 'moderate low-stable'. This finding suggested that very low levels of psychological control predict more aggressive behavior, but not that high levels predict less, because no positive association was found with trajectory classes that show higher levels of psychological control in comparison to the reference trajectory class with moderate levels.

For paternal parenting, the 'moderate-increasing' trajectory class of support was associated with a higher intercept of aggressive behavior in comparison to a reference trajectory class with higher levels of parental support. This finding was similar to the findings for maternal support, more specifically, that relative lack of support was associated with higher levels of aggressive behavior at age 12, even though 
the levels are still high and even increasing. Similar to the findings for maternal parenting, there was no significant association between paternal proactive control and punitive control, on the one hand, and the intercept or linear trend for aggressive behavior, on the other hand. The 'moderate low-stable' and 'moderate high-inverted U-shape' trajectory class of psychological control showed higher initial levels of aggressive behavior than the trajectory class with the lowest levels of psychological control. This pattern of findings seemed to indicate that paternal psychological control is associated with higher levels of aggressive behavior. It should be noted that this is inconsistent with the findings on maternal psychological control.

Rule-breaking behavior. The results for the trajectory classes of support are presented in Table $4 a$, for proactive control in Table $4 \mathrm{~b}$, for punitive control in Table $4 \mathrm{c}$ and for psychological control in Table 4d. Concerning gender, girls showed lower levels of rule-breaking behavior at age 12. For maternal parenting, there were no significant associations observed concerning the support dimension. Furthermore, the 'high-stable' trajectory class of proactive control showed less rule-breaking at age 12 than the trajectory class with very high levels of proactive control, whereas the 'moderate-stable' trajectory class did not show this significant negative association. This finding suggested that proactive control could limit rule-breaking behavior when it is applied with moderation. Concerning punitive control, the 'low-stable' and 'moderate low-decreasing' trajectory class showed a significant negative association with the intercept of rule-breaking behavior in comparison to moderate levels of punitive control. This finding indicated that lower levels of punitive control were associated with lower levels of rule-breaking behavior. There were no significant associations with the trajectory classes of maternal psychological control. Concerning paternal parenting, there were no significant associations with the trajectory classes for paternal support, proactive control, punitive control, or psychological control.

\section{Discussion}

The present study adds to the literature by associating membership to parenting trajectory groups, which provides information on longitudinal patterns of parenting, and aggressive (i.e., aggression, disruptive, and non-compliant behaviors) and rule-breaking behavior. This gives a more detailed picture of these associations since we assessed the evolution of subgroups based on parenting 
across adolescence. For four years, a large sample of adolescents from Grades 7 to 9 and their parents were annually invited to fill out questionnaires on parenting and externalizing problem behavior. This study (a) investigated whether there were meaningful trajectory classes distinguishable within the five measured parenting dimensions, and (b) assessed the association between trajectory class membership and the development of externalizing problem behavior between the ages of 12 and 17.

\section{Person-Centered Approach of Parenting}

Concerning support, the classes of mothers and fathers all fell in the moderate to very high range, which indicates that in a community sample parents perceive their own parenting as warm and supportive. This finding is in line with previous studies on how parents rate their own parenting (Laible et al., 2000; Pettit et al., 2001). We observed two classes of fathers, whereas three classes were found for maternal parenting. This may indicate that there are fewer inter-individual differences in paternal parenting (according to fathers) concerning support. The group of fathers that described their parenting as 'moderately' supportive was proportionally larger ( $25 \%$ of fathers) than the group of mothers that rated themselves as 'moderately' supportive ( $5 \%$ of mothers).

Regarding proactive control, the three classes of mothers were stable across adolescence, whereas two (out of four) classes of fathers showed a more variable trajectory. For instance, the largest group of fathers showed increasing levels of proactive control over the course of adolescence. A conclusive explanation for this trend is not readily available but it does indicate that there are larger differences in paternal parenting than in maternal parenting concerning proactive control.

Concerning punitive control, for both mothers and fathers, there were stable trajectories falling in the low, moderate, or high range. There was one smaller, fluctuating trajectory class of fathers, which showed an initial decline and a subsequent stronger increase in non-physical punishment. This finding of a variable paternal trajectory class is in line with the finding on proactive control.

Finally, regarding psychological control, the trajectory classes for mothers and fathers were similar, however the distribution differed slightly. Most fathers described their parenting as 'low' in psychological control, whereas most mothers fell in the 'moderate' range. 


\section{Concurrent Changes between Parental Trajectory Classes and Externalizing Problem Behavior}

A first general remark is that all the observed associations between parenting trajectory classes and externalizing problem behavior relate to the initial levels (i.e., at age 12) of aggressive and rulebreaking behavior, and not to the change across adolescence of aggressive and rule-breaking behavior. In this regard, there was no difference between maternal of paternal parenting. One possible explanation is the fact that the outcome variables were stable across adolescence. Although the decrease for aggressive behavior and the increase for rule-breaking behavior was significant, the changes across adolescence (i.e., slope) appeared to be small for both types of externalizing problem behavior. Consistent with the literature, aggressive behavior seemed to be slightly more stable across adolescence than rule-breaking behavior (Niv, Tuvblad, Raine, \& Baker, 2013), which potentially can be explained by a larger heritability as suggested by Burt et al. (2009).

Aggressive behavior across adolescence. The two trajectory classes of mothers of adolescents who exhibited more aggressive behavior at age 12 reported less support, which is consistent with previous studies (Hanisch et al., 2014; Laible et al., 2000). It should be noted that the term 'less' is relative in this case given that scores of the lowest trajectory class are around 3.5 on a 5-point scale, which is still high in comparison with scores on other parenting dimensions. The observation that all three trajectory classes reported moderate to high support may be an indication of its importance. Concerning punitive control, our findings indicated that the trajectory classes of mothers who reported lower levels of punitive control have adolescents that showed less aggressive behavior at age 12 . However, we did not observe that adolescents from mothers in the trajectory class characterized by higher punitive control exhibited more initial aggressive behavior. Furthermore, we also did not observe a significant association with the changes of aggressive behavior across adolescence, which is consistent with previous studies (Brenner \& Fox, 1998; Stormshak, et al., 2000). The findings concerning psychological control were inconsistent with the literature and suggested that adolescents who reported more aggressive behavior at age 12 had mothers who belonged to the trajectory class characterized by very low levels of psychological control, whereas we expected more aggression to be associated with more psychological control (Ahmad et al., 2013; Mabbe et al., 2016). However, there was no evidence that the mother trajectory class characterized by high levels of psychological control had adolescents 
that exhibited lower initial levels of aggressive behavior. In this context, it should be noted that not everyone is equally sensitive to manipulation of thoughts and emotions. Some people may experience a request from their mother as emotional blackmail, whereas others may consider it as a general request. This may lead to differences in what is considered psychological control, and thus be differently associated with adolescent behavior. In other words, it is possible that the low levels of psychological control that were found to be associated with lower levels of aggressive behavior at age 12 are not experienced as manipulative by everyone. It would be interesting to obtain more information on the subjective experience of psychological control by adolescents.

The findings on father reports of support and aggressive behavior were similar to the findings based on mother reports. Adolescents who reported more aggressive behavior at age 12 had fathers that belonged to the trajectory class characterized by lower levels of support. The same remark can be made here, that 'lower' levels of support still comprise a considerable amount of supportive behaviors. In contrast to maternal parenting, adolescents who reported more aggressive behavior at age 12 had fathers whose trajectory class was characterized by higher levels of psychological control, which is in line with the literature (Ahmad et al., 2013; Mabbe et al., 2016). Psychological control is a form of parental control, and as such it may prove useful in obtaining compliance of the adolescent. However, the literature generally suggests that psychological control is associated with higher levels of aggressive behavior (Ahmad et al., 2013; Mabbe et al., 2016). Further research is needed to clarify the function of psychological control and the apparent differences between mothers and fathers concerning this parenting practice.

Rule-breaking behavior across adolescence. Consistent with the literature (e.g. Bongers et al., 2004), there was a gender effect on rule-breaking behavior, more specifically, girls showed significantly lower levels at age 12. Concerning parenting, when mothers belonged to the trajectory class that reported high, but not very high levels of proactive control, adolescents reported less rule-breaking behavior age 12. The extent of proactive control and rule-breaking behavior do not show a linear relationship, since adolescents of the trajectory class of mothers characterized by even lower proactive control, do not exhibit significantly less rule-breaking. There seems to be an optimum concerning the level of maternal proactive control: although some rules are needed, the environment of the adolescent should not be 
“over-regulated". This way, adolescents could experience enough freedom to explore and to develop themselves. An alternative explanation is that the group of mothers characterized by high proactive control, does so, because their adolescent exhibits more rule-breaking behavior. However, the present study does not allow for causal conclusions. When mothers belonged to the trajectory class characterized by lower levels of punitive control, their adolescents showed less rule-breaking behavior at age 12. It has to be noted that the trajectory class of mothers that report higher levels of punishment is not linked with adolescents exhibiting more rule-breaking behavior. This finding is consistent with the findings on aggressive behavior. A causal interpretation of this finding is difficult. It may suggest that low levels of punishment are useful in limiting externalizing problem behavior at age 12 or that adolescents show less problem behavior and therefore, there is less need for parents to use punitive control (cfr. proactive control). In other words, does punitive control elicit externalizing problem behavior, vice versa, or both.

Concerning paternal parenting, there were no significant findings for rule-breaking behavior and support, which may indicate that small differences in paternal support are not associated with differences in rule-breaking behavior, whereas this is the case for maternal support. It is possible that adolescents are more sensitive to maternal support than to paternal support, in the context of rule-breaking behavior. Concerning paternal proactive control and punitive control, there were no significant associations with rule-breaking behavior. This is similar to the findings on aggressive behavior. In contrast to the findings on aggressive behavior, the findings on paternal psychological control and rule-breaking behavior did not show significant associations. This raises the question why paternal psychological control did predict aggressive behavior, but did not predict rule-breaking behavior. One possible explanation is that fathers are less involved in everyday rule setting, but get more involved when adolescents show more serious misbehavior, such as aggressive behavior.

\section{Combining a Person-Centered and Variable-Centered Approach}

The use of a combination of LCGA and conditional growth models in the current study provided additional information on parenting. The person-centered approach of LCGA offers the opportunity to distinguish groups of individuals in their use of certain parenting practices. In the current study, the person-centered approach is particularly interesting because it distinguishes groups longitudinally during a period in which parents have to adapt their parenting practices to the developing adolescent. 
Using this research design, it is not possible to establish whether the evolution of parenting practices causes or is caused by other factors, such as the behavior of the adolescent. An interesting future avenue for research is to investigate the parenting trajectory classes in more detail and to assess whether they differ on other variables, for instance, family composition, socioeconomic status, or the type of parenting their own parents used. Additionally, future research can address the issue of directionality. Specifically, does parenting evoke problem behavior, vice versa or both. Assessing the unique associations with externalizing problem behavior of subpopulations for each of these five parenting dimensions separately can assist in understanding the mechanisms through which developmental outcomes are positively or negatively affected by parenting practices. Such insights, in turn, can inspire clinical practice. Interventions can be designed to specifically target a subpopulation for a specific parenting dimension.

\section{Clinical Implications}

The findings of the present study provided support for a family-based approach in prevention and intervention of externalizing problem behavior. Both mothers and fathers seem to play a role in the development of problem behavior in their children, however, we found that maternal and paternal parenting practices show different associations with problem behavior. Future prevention and intervention programs should involve both mothers and fathers in order to attain optimal results. In line with previous studies, taking into account the degree of discrepancy/agreement in the perspectives on parenting between informants (i.e., mother and father and/or parent and adolescent) is crucial in designing effective parenting programs (Moens et al., 2018; Van Roy, Groholt, Heyerdahl, \& ClenchAas, 2010). Moreover, when both parents take responsibility in childrearing, it may be advisable to ask to what extent they support each other's parenting. Furthermore, the results refuted some assumptions on associations between certain parenting practices and problem behavior, which can have practical implications. For instance, proactive control is generally considered to be a positive parenting practice, but the present study showed that it can become problematic when parenting becomes too stringent. Our findings also provided information on the timing of prevention and intervention efforts. Specifically, it is important to address parenting practices early in adolescence and consistently across time in order to limit externalizing problem behavior in adolescence.

\section{Limitations}


A number of limitations should be noted concerning this study. First, an important limitation is the fact that adolescent reports are used to assess the level of externalizing problem behavior. It is possible that social desirability plays a role and that adolescents underreport their aggressive behavior and rule-breaking behavior, which in turn would attenuate the associations with externalizing problem behavior that were observed in the present study. Related to this point is that a combination of observational data and questionnaire data could have provided a more detailed view on parenting and externalizing problem behavior. However, observational data have their own limitations, such as observer effects and the fact that they only provide information about one, particular moment. Second, it is unknown to what extent mothers and fathers are involved in the upbringing of their child. This study asked them about their parenting practices, while it is possible that one of the parents is less involved in parenting. This could be a potential source of noise in the data. However, it is very difficult, if not impossible, to map these differences in involvement. On a related note, it would be interesting to investigate to what extent parents agree or disagree on their parenting behaviors and whether this disagreement is associated with problem behavior of the adolescent. Third, gender was included as a control variable in the prediction of externalizing problem behavior. A number of other factors may also prove interesting in the context of externalizing problem behavior in adolescence. A few examples are Social Economic Status (SES), family composition, or living situation. However, it should be noted that including separate demographic variables as predictors of externalizing problem behavior may prove difficult. Instead of a single variable, it is rather the interplay of a large number of variables that influence the emergence and maintenance of externalizing problem behavior. Fourth, previous studies (Fanti \& Henrich, 2010; Ingoldsby et al., 2006) suggested a robust co-occurrence of externalizing and internalizing problem behavior. However, ratings of YSR internalizing behaviors were not available in the present study, therefore it was not possible to investigate co-occurring trajectories of internalizing and externalizing problems. Fifth, the present study did not take into account externalizing problem behavior in childhood. The literature suggests that developmental changes in parent-child relationship quality differ for different types of offenders (Keijsers, Loeber, Branje, \& Meeus, 2012). Future additional research on the transition from childhood into adolescence may prove interesting for intervention and prevention purposes. Finally, it should be noted that some of the trajectory classes 
showed small sample sizes (e.g., $N=9$ ), and thus we should be cautious when drawing conclusions about these classes of parents. However, although these small classes seem to represent less common or even rare- cases within a community sample, they may be more common in clinical samples (e.g., parents showing problematic parenting; being 'at risk' groups) and thus they are worthwhile to consider.

\section{Conclusion}

In conclusion, several trajectory classes can be distinguished in the longitudinal perceptions by mothers and fathers of their parental behavior (i.e., parental support, proactive control, punitive control, harsh punitive control, and psychological control). Paternal parenting dimensions seem to be less stable than maternal parenting dimensions. However, it should be noted that the largest trajectory classes are similar but that in father reports more variable trajectory classes can be found. Overall, the beneficial effects of support are confirmed across parents. It appears that relatively small differences in support are already associated with differences in aggressive behavior. Concerning maternal proactive control, our results suggest that there is an optimal level for setting rules and monitoring adolescent behavior. Proactive control seems to be useful to provide a stable environment for adolescents, but not when it over-regulates their lives and constrains their freedom. Furthermore, the group of mothers that frequently uses non-physical punishment has adolescents that exhibit more rule-breaking behavior, but not aggressive behavior. This finding is not replicated in the father reports. Finally, our results suggest that when the father belongs to a trajectory class that uses more psychological control, the adolescents exhibits more aggressive behavior at age 12. However, when mother is using psychological control, the association with aggressive behavior seems to be more complex (i.e., non-linear). All observed associations concerned externalizing problem behavior at age 12, our results showed no associations with the change of externalizing problem behavior across adolescence. 


\section{References}

Achenbach, T. M. (1991). Manual for the Youth Self-Report and 1991 Profile. Burlington, VT: University of Vermont, Department of Psychiatry.

Ahmad, I., Vansteenkiste, M., \& Soenens, B. (2013). The relations of Arab Jordanian adolescents' perceived maternal parenting to teacher-rated adjustment and problems: The intervening role of perceived need satisfaction. Developmental Psychology, 49, 177-83. doi: 10.1037/a0027837

Armstrong, R.A., (2014). When to use the Bonferroni correction. Ophthalmic and Physiological Optics, 34: 502-508. doi: 10.1111/opo.12131

Asendorpf, J.B., van de Schoot, R., Denissen, J.J.A., \& Hutteman, R. (2014). Reducing bias due to systematic attrition in longitudinal studies: The benefits of multiple imputation. International Journal of Behavioral Development, 38, 353-460. doi: 10.1177/0165025414542713

Assor, A., Roth, G., \& Deci, E. L. (2004). The emotional costs of parents' conditional regard: A selfdetermination theory analysis. Journal of Personality, 72, 47-88.

Barber, B. K. (1996). Parental psychological control: Revisiting a neglected construct. Child Development, 67(6), 3296-319. doi: 10.1111/j.1467-8624.1996.tb01915.x

Barber, B. K. (2002). Regulation as a multicultural concept and construct for adolescent health and development. Unpublished manuscript, University of Tennessee, Knoxville.

Barber, B. K., Olsen, J. E., \& Shagle, S. C. (1994). Associations between parental psychological and behavioral control and youth internalized and externalized behaviors. Child Development, 65, 1120-1136. doi: 10.2307/1131309

Barber, B. K., Stolz, H. E., \& Olsen, J. A. (2005). Parental support, psychological control, and behavioral control: Assessing relevance across time, method, and culture. Monographs of the Society for Research in Child Development, 70 (7, Serial No. 276

Baumrind, D. (1967). Child care practices anteceding three patterns of preschool behavior. Genetic Psychology Monographs, 75, 43-88.

Baumrind, D. (1971). Current patterns of parental authority. Developmental Psychology Monographs, 4, 1-103. doi: $10.1037 / \mathrm{h} 0030372$

Baumrind, D. (1996). The discipline controversy revisited. Family Relations, 45, 405-414. 
Beauchaine, T.P. \& McNulty, T. (2013). Comorbidities and continuities as ontogenic processes: Toward a developmental spectrum model of externalizing psychopathology. Development and Psychopathology, 25, 1505-1528. doi: 10.1017/S0954579413000746

Bender, H. L., Allen, J. P., McElhaney, K. B., Antonishak, J., Moore, C. M., Kelly, H. O., \& Davis, S. M. (2007). Use of harsh physical discipline and developmental outcomes in adolescence. Development and Psychopathology, 19, 227-42. doi: 10.1017/S0954579407070125

Berndt, T.J. (1979). Developmental changes in conformity to peers and parents. Developmental Psychology, 15, 608-616.

Bongers, I. L., Koot, H. M., van der Ende, J. van der Ende, \& Verhulst, F. C. (2004). Developmental trajectories of externalizing behaviors in childhood and adolescence. Child Development, 75, $1523-1537$.

Brenner, V., \& Fox, R. A. (1998). Parental discipline and behavior problems in young children. Journal of Genetic Psychology, 159, 251-256. doi: 10.1080/00221329809596149

Bronstein, P., Fox, B. J., Kamon, J. L., \& Knolls, M. L. (2007). Parenting and gender as predictors of moral courage in late adolescence: A longitudinal study. Sex Roles: A Journal of Research, 56, 661-674. doi: 10.1007/s11199-007-9182-8

Browne, M. W., \& Cudeck, R. (1992). Alternative ways of assessing model fit. Sociological Methods \& Research, 21, 230-258.

Burt, S.A. (2009). Are there meaningful etiological differences within antisocial behavior? Results of a meta-analysis. Clinical Psychology Review, 29, 163-178.

Burt, S.A. (2013). Do etiological influences on aggression overlap with those on rule breaking? A metaanalysis. Psychological Medicine, 43, 1801-1812. doi: 10.1017/S0033291712001894

Chen, F. F. (2008). What happens if we compare chopsticks with forks? The impact of making inappropriate comparisons in cross-cultural research. Journal of Personality and Social Psychology, 95, 1005-1018. doi: 10.1037/a0013193

Darling, N., \& Steinberg, L. (1993). Parenting style as context: An integrative model. Psychological Bulletin, 113, 487-496. doi: 10.1037/0033-2909.113.3.487 
De Groot, A., Koot, H. M., \& Verhulst, F. C. (1994). Cross-cultural generalizability of the Child Behavior Checklist cross-informant syndromes. Psychological Assessment, 6, 225-230.

De Haan, A. D., Prinzie, P., \& Deković, M. (2012). Change and reciprocity in adolescent aggressive and rule-breaking behaviors and parental support and dysfunctional discipline. Development and Psychopathology, 24, 301-15. doi: 10.1017/S0954579411000848

Delhaye, M., Beyers, W., Klimstra, T. A., Linkowski, P., \& Goossens, L. (2012). The Leuven Adolescent Perceived Parenting Scale (LAPPS): Reliability and validity with French-speaking adolescents in Belgium. Psychologica Belgica, 52, 289-305. doi: 10.5334/pb-52-4-289

Denham, S. A., Workman, E., Cole, P. M., Weissbrod, C., Kendziora, K. T., \& Zahn-Waxler, C. (2000). Prediction of externalizing behavior problems from early to middle childhood: The role of parental socialization and emotion expression. Development and Psychopathology, 12, 23-45. doi: 10.1017/S0954579400001024

Eichelsheim, V. I., Buist, K. L., Deković, M., Wissink, I. B., Frijns, T., Van Lier, P. A. C., ... Meeus, W. H. J. (2010). Associations among the parent-adolescent relationship, aggression and delinquency in different ethnic groups: A replication across two Dutch samples. Social Psychiatry and Psychiatric Epidemiology, 45, 293-300. doi: 10.1007/s00127-009-0071-z

Fanti, K. A., \& Henrich, C. C. (2010). Trajectories of pure and co-occurring internalizing and externalizing problems from age 2 to age 12: Findings from the national institute of child health and human development study of early child care. Developmental Psychology, 46, 1159-1175.

Feldman, B.J., Masyn, K.E., \& Conger, R.D. (2009). New approaches to studying problem behaviors: A comparison of methods for modeling longitudinal, categorical adolescent drinking data. Developmental Psychology, 45, 652-676. doi: 10.1037/a0014851

Finney, S. J., \& DiStefano, C. (2008). Non-normal and categorical data in structural equation modeling. In G. R. Hancock \& R. D. Mueller (Eds.), Structural Equation Modeling: A Second Course (pp. 269-314). Information Age Publishing.

Galambos, N. L., Barker, E. T., \& Almeida, D. M. (2003). Parents do matter: Trajectories of change in externalizing and internalizing problems in early adolescence. Child Development, 74, 578-594. doi: $10.1111 / 1467-8624.7402017$ 
Gershoff, E. T., \& Grogan-Kaylor, A. (2016). Spanking and child outcomes : Old controversies and new meta-analyses. Journal of Family Psychology, 30, 453-469.

Gray, M. R., \& Steinberg, L. (1999). Unpacking authoritative parenting: Reassessing a multidimensional construct. Journal of Marriage and Family, 61, 574-587. doi: 10.2307/353561

Grolnick, W. S., Ryan, R. M., \& Deci, E. L. (1991). Inner resources for school achievement: Motivational mediators of children's perceptions of their parents. Journal of Educational Psychology, 83, 508-517. doi:10.1037/0022-0663.83.4.508

Grusec, J. E., \& Davidov, M. (2010). Integrating different perspectives on socialization theory and research: A domain-specific approach. Child Development, 81, 687-709. doi: 10.1111/j.14678624.2010.01426.x

Hanisch, C., Hautmann, C., Plück, J., Eichelberger, I., \& Döpfner, M. (2014). The prevention program for externalizing problem behavior (PEP) improves child behavior by reducing negative parenting: Analysis of mediating processes in a randomized controlled trial. Journal of Child Psychology and Psychiatry and Allied Disciplines, 55, 473-484. doi: 10.1111/jcpp.12177

Hicks, B.M., Bloningen, D.M., Kramer, M.D., Krueger, R.F., Patrick, C.J., Iacono, W.G., \& Mcgue, M. (2007). Gender differences and developmental change in externalizing disorders from late adolescence to early adulthood: A longitudinal twin study. Journal of Abnormal psychology, 116, 433-447. doi: 10.1037/0021-843X.116.3.433

Hoeve, M., Dubas, J. S., Gerris, J. R., van der Laan, P. H., \& Smeenk, W. (2011). Maternal and paternal parenting styles: Unique and combined links to adolescent and early adult delinquency. Journal of Adolescence, 34, 813-827. doi: 10.1016/j.adolescence.2011.02.004

Hu, L., \& Bentler, P. M. (1999). Cutoff criteria for fit indexes in covariance structure analysis: Conventional criteria versus new alternatives. Structural Equation Modeling: A Multidisciplinary Journal, 6, 1-55. doi: 10.1080/10705519909540118

Hubbard, A.E., Ahern, J., Fleischer, N.L., Van der Laan, M., Lippman, S.A., Jewell, N., Bruckner, T., ..., Satariano, W.A. (2010). To GEE or not to GEE: Comparing population average and mixed models for estimating the associations between neighborhood risk factors and health. Epidemiology, 21, 467-474. 
Ingoldsby, E.M., Kohl, G.O., McMahon, R.J., Lengua, L., \& The conduct problems prevention research group. (2006). Conduct problems, depressive symptomatology and their co-occurring presentation in childhood as predictors of adjustment in early adolescence. Journal of Abnormal Child Psychology, 34, 603-621.

Institute for Research and Reform in Education. (1998). Research Assessment Package for Schools (RAPS) manual. Retrieved from http://www.irre.org/sites/default/files/publication_pdfs/ RAPS_manual_entire_1998.pdf

Janssens, A., Goossens, L., Van Den Noortgate, W., Colpin, H., Verschueren, K., \& Van Leeuwen, K. (2015). Parents' and adolescents' perspectives on parenting: Evaluating conceptual structure, measurement invariance, and criterion validity. Assessment, 22(4), 473-489. doi: $10.1177 / 1073191114550477$

Jeynes, W. H. (2016). Meta-analysis on the roles of fathers in parenting: Are they unique? Marriage \& Family Review, 52, 665-88. doi: 10.1080/01494929.2016.1157121

Jung, T., \& Wickrama, K. A. (2008). An introduction to latent class growth analysis and growth mixture modeling. Social and Personality Psychology Compass, 2(1), 302-317. doi: 10.1111/j.17519004.2007.00054.x

Keijsers, L., Loeber, R., Branje, S., \& Meeus, W. (2012). Parent-child relationships of boys in different offending trajectories: A developmental perspective. Journal of Child Psychology and Psychiatry, 53, 1222-1232. doi: 10.1111/j.1469-7610.2012.02585.x

King Baudouin Foundation. (2008). Het kind in een nieuw samengesteld gezin. [The child in a blended

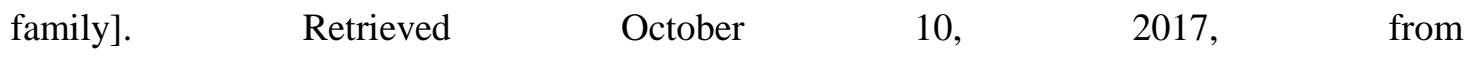
https://www.kbsfrb.be/ /media/Files/Bib/Publications/Older/PUB-1838NieuwSamengesteldeGezinnen.pdf

Laible, D. J., Carlo, G., \& Raffaelli, M. (2000). The differential relations of parent and peer attachment to adolescent adjustment. Journal of Youth and Adolescence, 29, 45-59. doi: 10.1023/A

Lansford, J. E., Criss, M. M., Laird, R. D., Shaw, D. S., Pettit, G. S., Bates, J. E., \& Dodge, K. A. (2011). Reciprocal relations between parents' physical discipline and children's externalizing behavior 
during middle childhood and adolescence. Development and Psychopathology, 23, 225-238. doi: $10.1017 / \mathrm{S} 0954579410000751$

Larzelere, R. E., Cox, R. B. J., \& Smith, G. L. (2010). Do nonphysical punishments reduce antisocial behavior more than spanking? A comparison using the strongest previous causal evidence against spanking. BMC Pediatrics, 10, 1-17.

Lo, Y., Mendell, N.R., \& Rubin, D.B. (2001). Testing the number of components in a normal mixture. Biometrika, 88, 767-778. doi: 10.1093/biomet/88.3.767

Luyckx, K., Tildesley, E. A., Soenens, B., Andrews, J. A., Hampson, S. E., Peterson, M., \& Duriez, B. (2011). Parenting and trajectories of children's maladaptive behaviors: A 12-year prospective community study. Journal of Clinical Child and Adolescent Psychology, 40, 468-478. doi: $10.1080 / 15374416.2011 .563470$

Mabbe, E., Soenens, B., Vansteenkiste, M., \& Van Leeuwen, K. (2016). Do personality traits moderate relations between psychologically controlling parenting and problem behavior in adolescents? Journal of Personality, 84, 381-392. doi: 10.1017/CBO9781107415324.004

Mandara, J. (2003). The typological approach in child and family psychology: A review of theory, methods, and research. Clinical Child and Family Psychology Review, 6, 129-146.

Moens, M. A., Weeland, J., Van der Giessen, D., Chhangur, R. R., \& Overbeek, G. (2018). In the eye of the beholder? Parent-observer discrepancies in parenting and child disruptive behavior assessments. Journal of Abnormal Child Psychology, 46, 1147-59. doi: 10.1007/s10802-017$0381-7$

Muthén, L.K. and Muthén, B.O. (1998-2012). Mplus user's guide $\left(7^{\text {th }}\right.$ ed.). Los Angeles, CA: Muthén \& Muthén

Nelson, D. A., \& Crick, N. R. (2002). Parental psychological control: Implications for childhood physical and relational aggression. In B. K. Barber (Ed.), Intrusive parenting: How psychological control affects children and adolescents (pp. 168-189). Washington, DC: American Psychological Association. 
Niv, S., Tuvblad, C., Raine, A., \& Baker, L.A. (2013). Aggression and rule-breaking: Heritability and stability of antisocial behavior problems in childhood and adolescence. Journal of Criminal Justice, 41, 285-291. doi: 10.1016/j.jcrimjus.2013.06.014

Nylund, K. L., Asparouhov, T., \& Muthen, B. O. (2007). Deciding on the number of classes in latent class analysis and growth mixture modeling: A Monte Carlo simulation study. Structural Equation Modeling: A Multidisciplinary Journal, 14, 535-569. doi: $10.1080 / 10705510701575396$

Okado, Y., \& Haskett, M. E. (2015). Three-year trajectories of parenting behaviors among physically abusive parents and their link to child adjustment. Child and Youth Care Forum, 44, 613-633. doi: $10.1007 / \mathrm{s} 10566-014-9295-5$

Pettit, G. S., Bates, J. E., \& Dodge, K. A. (1997). Supportive parenting, ecological context, and children's adjustment: A seven-year longitudinal study. Child Development, 68, 908-923.

Pettit, G. S., Laird, R. D., Dodge, K. A., Bates, J. E., \& Criss, M. M. (2001). Antecedents and behaviorproblem outcomes of parental monitoring and psychological control in early adolescence. Child Development, 72, 583-598. doi: 10.1111/1467-8624.00298

Reef, J., Diamantopoulou, S., van Meurs, I., Verhulst, F., \& van der Ende, J. (2010). Predicting adult emotional and behavioral problems from externalizing problem trajectories in a 24-year longitudinal study. European Child \& Adolescent Psychiatry, 19, 577-585. doi: 10.1007/s00787010-0088-6

Reitz, E., Dekovic, M., \& Meijer, A. M. (2005). The structure and stability of externalizing and internalizing problem behavior during early adolescence. Journal of Youth and Adolescence, 34, 577-588. doi: 10.1007/s10964-005-8947-z

Research Department of the Flemish Government. (2010). Activiteitsgraad naar geslacht, leeftijdsgroep en internationale vergelijking, in \%. [Activity level by sex, age group and international comparison, in \%]. Retrieved April 19, 2016, from http://bi-vijfzes.deboeck.com/public/modele/bi-vijfzes/content/bivijf/Module\%203/Hoofdstuk\%204/activiteitsgraad\%20internationaal.xlsx. 
Research Department of the Flemish Government. (2011). Scholingsgraad van de bevolking (25-64 jaar), in \%.[Level of education of the population (25-64 years old), in \%]. Retrieved May 12, 2015 , from http://www4dar.vlaanderen.be/sites/svr/Cijfers/Exceltabellen/onderwijs/kwaliteitszorg/ONDE KWAL012.xls

Scalco, M.D., Colder, C.R., Hawk Jr., L.W., Read, J.P., Wieczorek, W., \& Lengua, L.J. (2014). Internalizing and externalizing problem behavior and early adolescent substance use: A test of latent variable interaction and conditional indirect effects. Psychology of Addictive Behaviors, 28, 828-840. doi: 10.1037/a0035805

Schludermann, E, \& Schludermann, S. (1988). Children's Report on Parent Behavior (CRPBI-108, CRPBI-30). Winnipeg, Canada: Unpublished manuscript, Department of Psychology, University of Manitoba.

Steinberg, L.D. \& Silverberg, S.B. (1986) The vicissitudes of autonomy in early adolescence. Child Development. 57:841-851.

Sterne, J. A. C., White, I. R., Carlin, J. B., Spratt, M., Royston, P., Kenward, M. G., .., Carpenter, J. R. (2009). Multiple imputation for missing data in epidemiological and clinical research: Ptential and pitfalls. BMJ;338:b2393.

Socolar, R. R. S. (1997). A classification scheme for discipline: Type, mode of administration, context. Aggression and Violent Behavior, 2, 355-364. doi: 10.1016/S1359-1789(97)00021-9

Soenens, B., Sierens, E., Vansteenkiste, M., Dochy, F., \& Goossens, L. (2012). Psychologically controlling teaching: Examining outcomes, antecedents, and mediators. Journal of Educational Psychology, 104, 108-120. doi: 10.1037/a0025742

Soenens, B., Vansteenkiste, M., Luyckx, K., \& Goossens, L. (2006). Parenting and adolescent problem behavior: An integrated model with adolescent self-disclosure and perceived parental knowledge as intervening variables. Developmental Psychology, 42, 305-318. doi: 10.1037/0012-1649.42.2.305

Steinberg, L. (2001). We know some things: Parent-adolescent relationships in retrospect and prospect. Journal of Research on Adolescence, 11, 1-19. doi: 10.1111/1532-7795.00001 
Stice, E., Barrera, M. J., \& Chassin, L. (1993). Relation of parental support and control to adolescents' externalizing symptomatology and substance use: A longitudinal examination of curvilinear effects. Journal of Abnormal Child Psychology, 21, 609-629.

Stormshak, E. A., Bierman, K. L., McMahon, R. J., \& Lengua, L. J. (2000). Parenting practices and child disruptive behavior problems in early elementary school. Journal of Clinical Child Psychology, 29, 30-42. doi: 10.1207/S15374424jccp2901

Tang, S., \& Davis-Kean, P. E. (2015). The association of punitive parenting practices and adolescent achievement. Journal of Family Psychology, 29, 873-883. doi:10.1037/fam0000137

Tuggle, F. J., Kerpelman, J. L., \& Pittman, J. F. (2014). Parental support, psychological control, and early adolescents' relationships with friends and dating partners. Family Relations, 63(4), 496512. doi: 10.1111/fare. 12080

Van Heel, M., Bijttebier, P., Claes, S., Colpin, H., Goossens, L., Van Den Noortgate, W., Verschueren, K., \& Van Leeuwen, K. (2017). Measuring parenting throughout adolescence: Measurement invariance across informants, mean level, and differential continuity. Assessment, 1-17. doi : $10.1177 / 1073191116686827$

Van Leeuwen, K., Vermulst, A., Kroes, G., De Meyer, L., \& Veerman, J. W. (2015). Handleiding VSOG: Verkorte Schaal voor Ouderlijk Gedrag [Brief Scale of Parental Behavior]. Nijmegen, Netherlands: Praktikon.

Van Roy, B., Groholt, B., Heyerdahl, S., \& Clench-Aas, J. (2010). Understanding discrepancies in parent-reporting of emotional and behavioural problems: Effects of relational and sociodemographic factors. BMC Psychiatry, 10.

Videon, T. M. (2005). Parent-child relations and children's ssychological well-being: Do dads matter? Journal of Family Issues, 26(1), 55-78. doi: 10.1177/0192513X04270262

Wang, M.-T., \& Kenny, S. (2014). Parental physical punishment and adolescent adjustment: Bidirectionality and the moderation effects of child ethnicity and parental warmth. Journal of Abnormal Child Psychology, 42, 717-30. doi: 10.1007/s10802-013-9827-8 
Winsler, A., Madigan, A. L., \& Aquilino, S. A. (2005). Correspondence between maternal and paternal parenting styles in early childhood. Early Childhood Research Quarterly, 20, 1-12. doi: 10.1111/j.1467-8624.2011.01639.x 


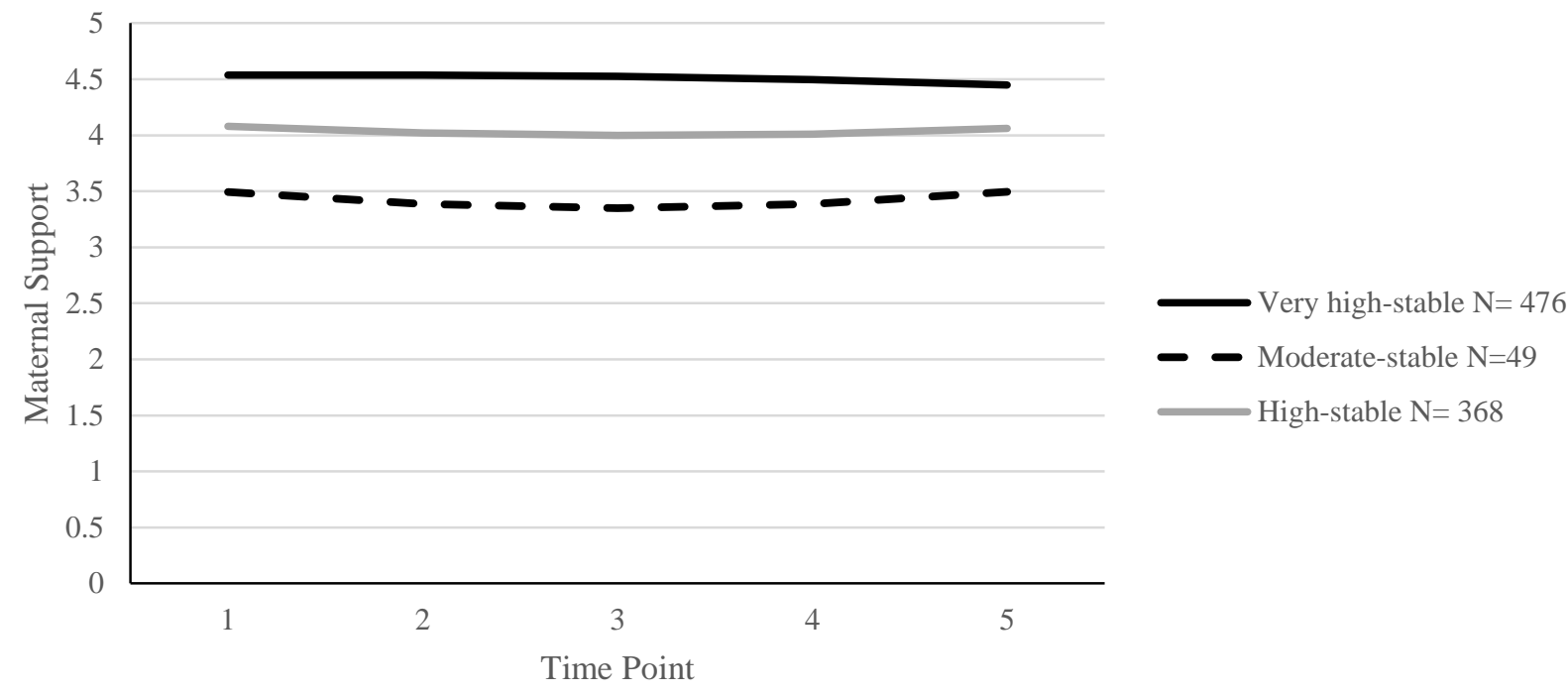

Figure 1a. Trajectory classes for parental support as reported by mothers across ages 12 to 17 .

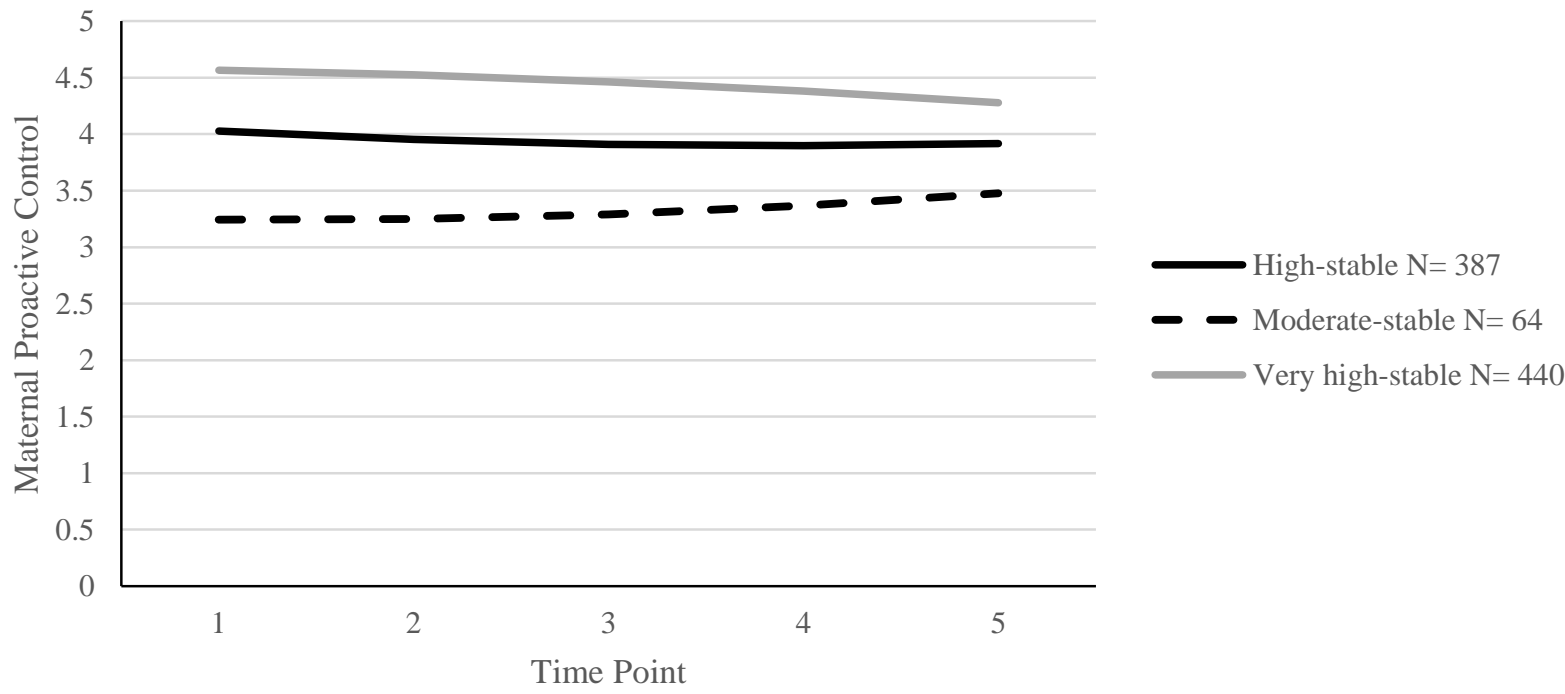

Figure $1 b$. Trajectory classes for proactive control as reported by mothers across ages 12 to 17 . 


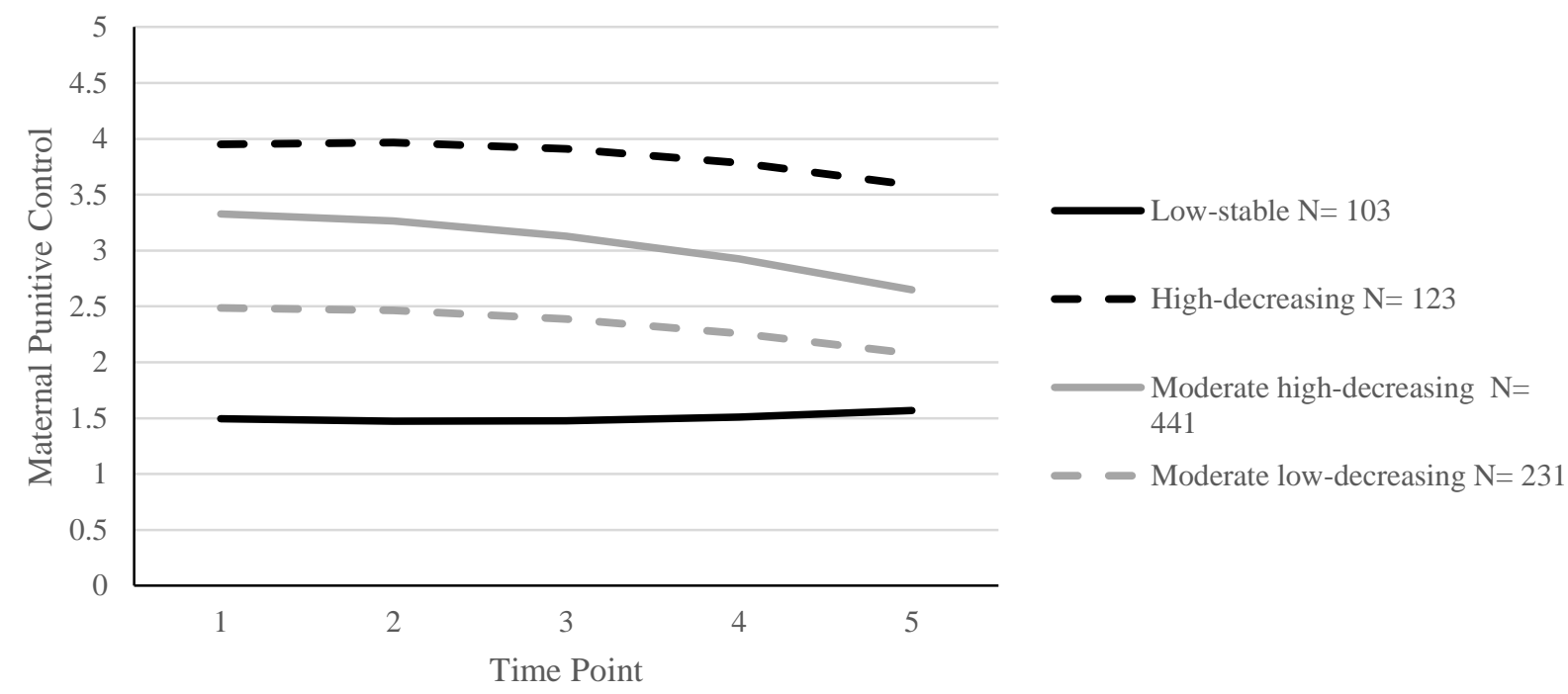

Figure 1c. Trajectory classes for punitive control as reported by mothers across ages 12 to 17 .

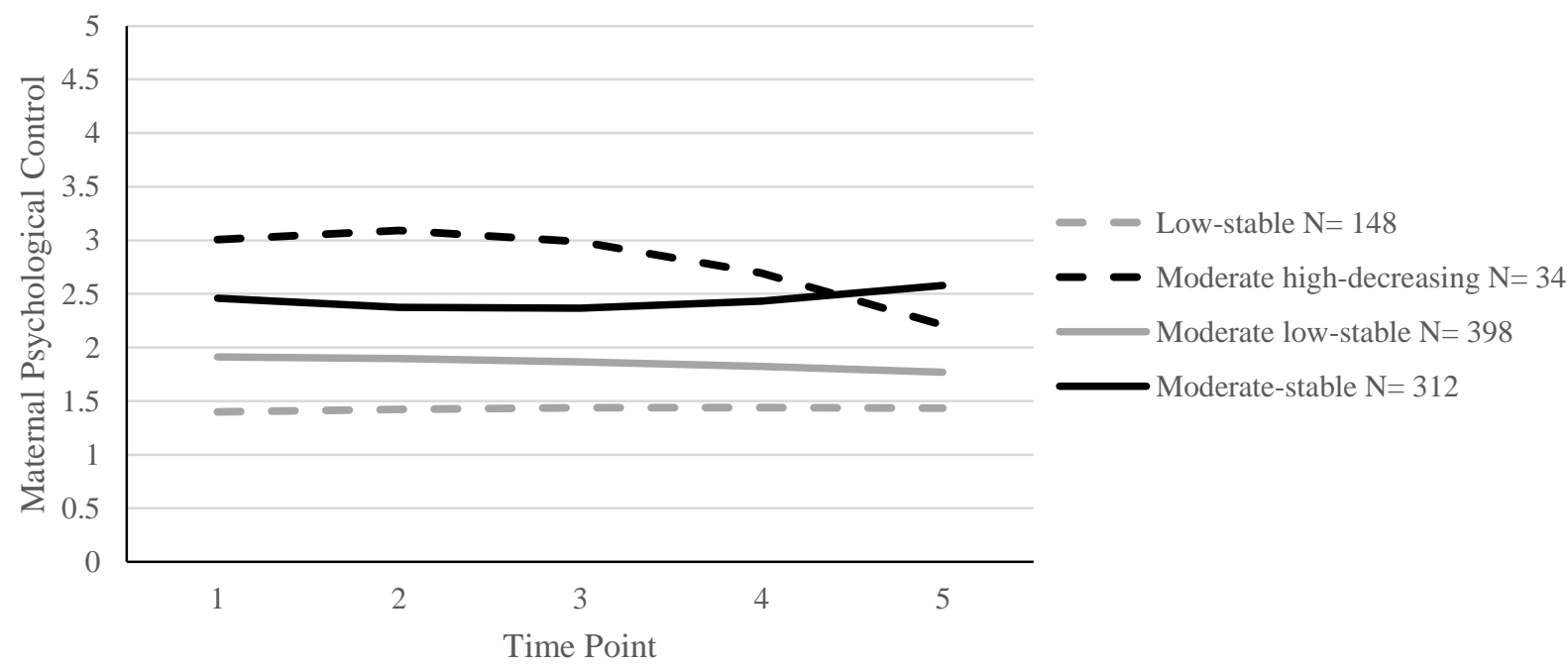

Figure 1d. Trajectory classes for psychological control as reported by mothers across ages 12 to 17 . 


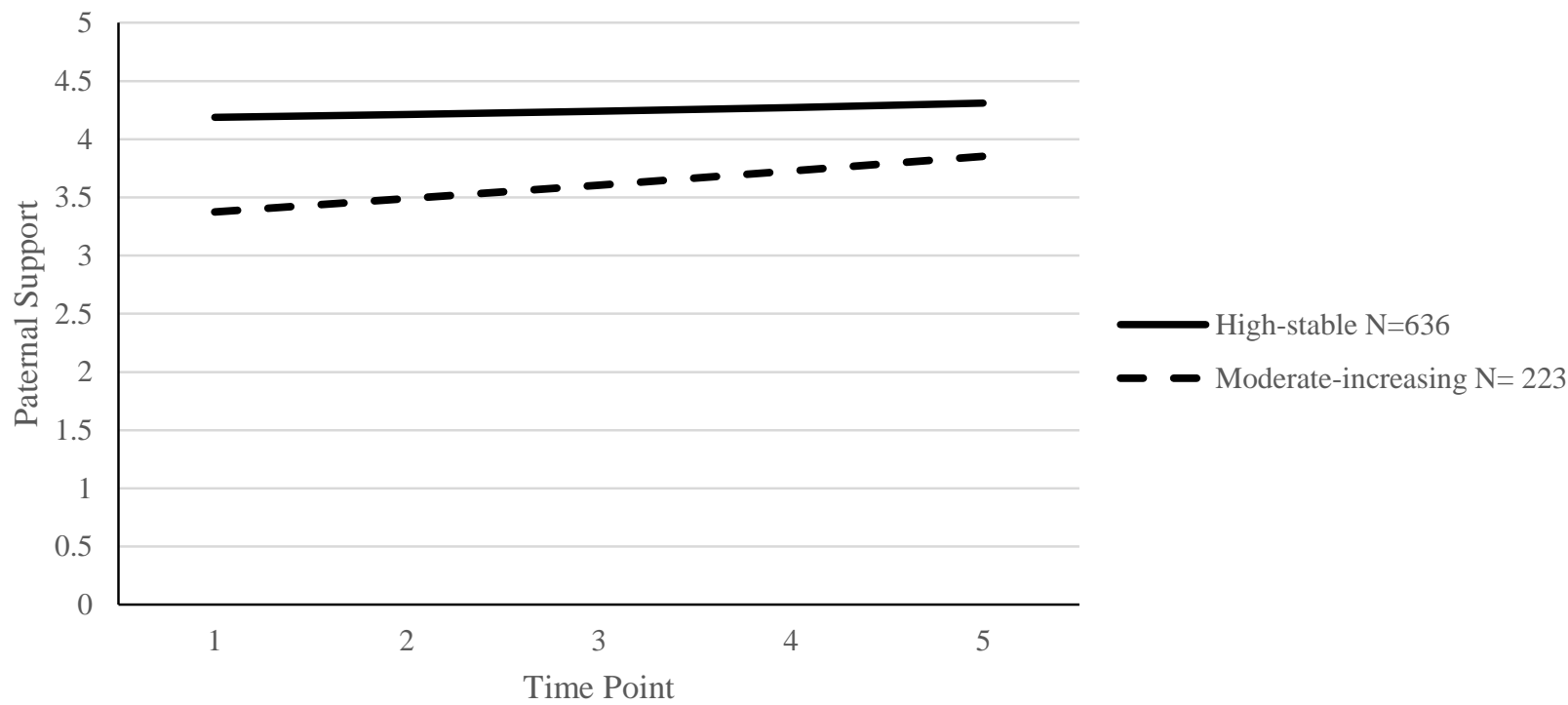

Figure $2 a$. Trajectory classes for parental support as reported by fathers across ages 12 to 17 .

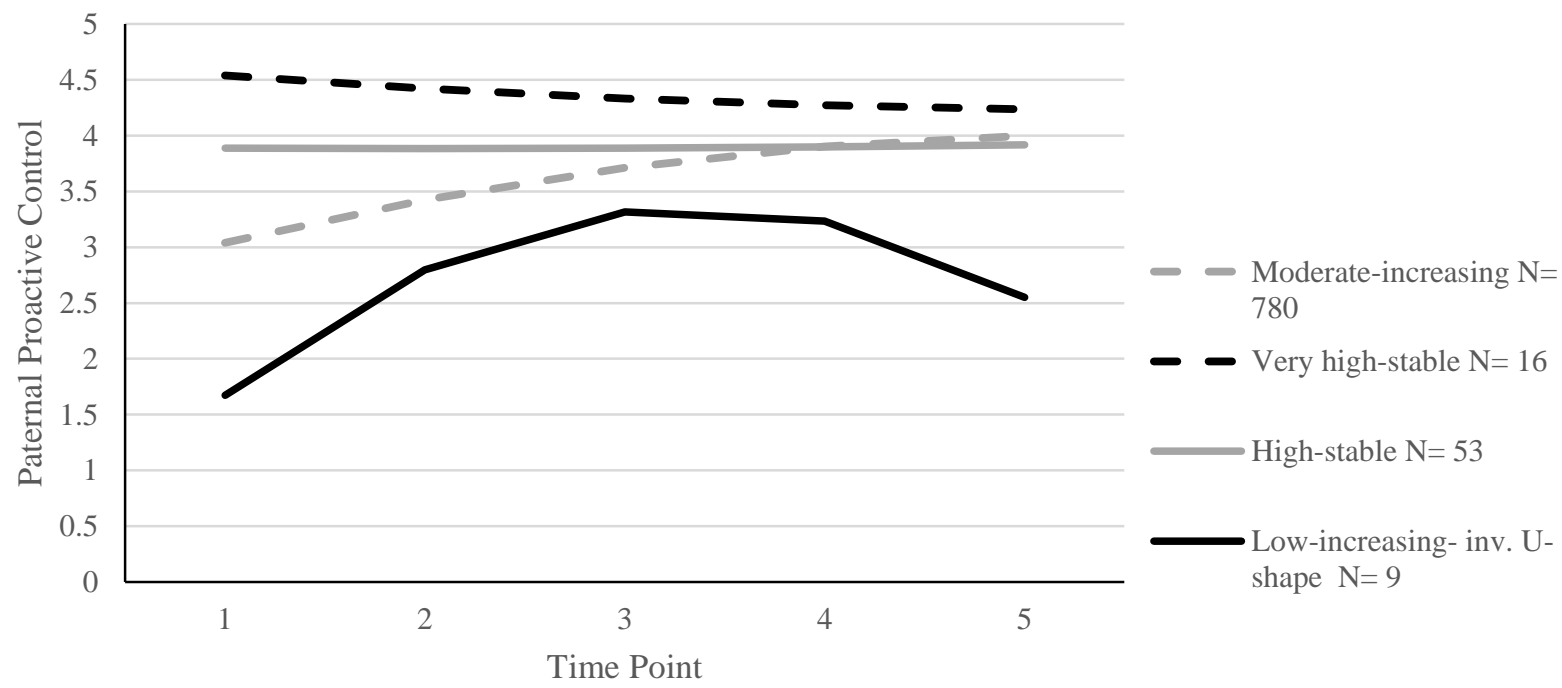

Figure $2 b$. Trajectory classes for proactive control as reported by fathers across ages 12 to 17 . 


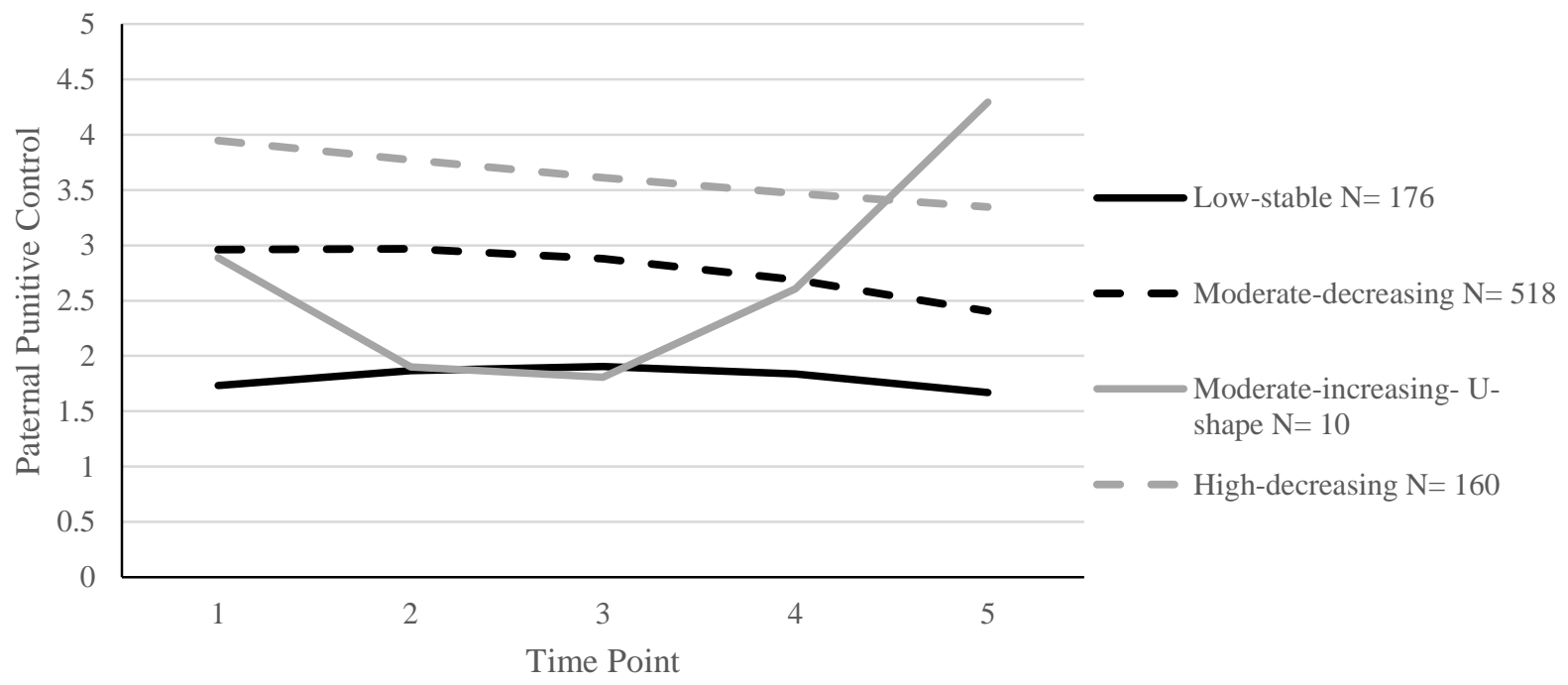

Figure $2 c$. Trajectory classes for punitive control as reported by fathers across ages 12 to 17 .

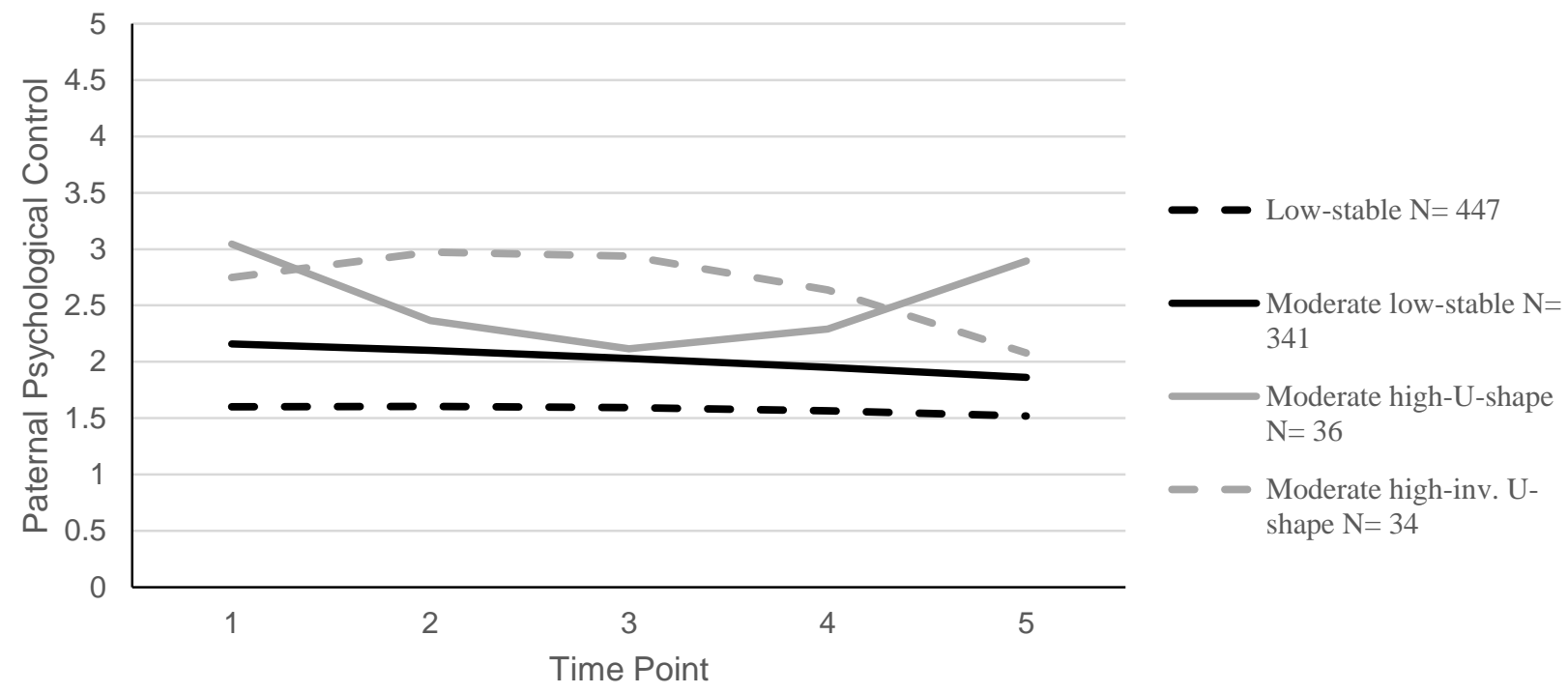

Figure $2 d$. Trajectory classes for psychological control as reported by fathers across ages 12 to 17 . 
Table 1

Descriptive Statistics of the Five Parenting Dimensions (Reported by Father and Mother) and RuleBreaking and Aggressive Behavior (Reported by Adolescents) Across Six Time Points.

\begin{tabular}{|c|c|c|c|c|c|c|c|}
\hline \multirow{2}{*}{ informant } & \multirow{3}{*}{ Variable } & \multicolumn{6}{|c|}{$M\left(S^{2}\right)$} \\
\hline & & \multicolumn{6}{|c|}{ Time point } \\
\hline & & T1 & $\mathrm{T} 2$ & T3 & $\mathrm{T} 4$ & T5 & T6 \\
\hline \multirow[t]{7}{*}{ Mother } & Support & $\begin{array}{l}4.00 \\
(0.29)\end{array}$ & $\begin{array}{l}3.97 \\
(0.25)\end{array}$ & $\begin{array}{l}4.06 \\
(0.27)\end{array}$ & $\begin{array}{l}4.11 \\
(0.25)\end{array}$ & $\begin{array}{l}4.14 \\
(0.21)\end{array}$ & $\begin{array}{l}3.91 \\
(0.39)\end{array}$ \\
\hline & $\begin{array}{l}\text { Proactive } \\
\text { control }\end{array}$ & $\begin{array}{l}4.05 \\
(0.38)\end{array}$ & $\begin{array}{l}4.00 \\
(0.26)\end{array}$ & $\begin{array}{l}4.05 \\
(0.30)\end{array}$ & $\begin{array}{l}4.04 \\
(0.27)\end{array}$ & $\begin{array}{l}4.00 \\
(0.31)\end{array}$ & $\begin{array}{l}3.84 \\
(0.34)\end{array}$ \\
\hline & $\begin{array}{l}\text { Punitive } \\
\text { control }\end{array}$ & $\begin{array}{l}2.96 \\
(0.81)\end{array}$ & $\begin{array}{l}2.83 \\
(0.75)\end{array}$ & $\begin{array}{l}2.79 \\
(0.77)\end{array}$ & $\begin{array}{l}2.73 \\
(0.81)\end{array}$ & $\begin{array}{l}2.44 \\
(0.80)\end{array}$ & $\begin{array}{l}2.25 \\
(0.79)\end{array}$ \\
\hline & Harsh punitive & 1.12 & 1.09 & 1.08 & 1.05 & 1.04 & 1.01 \\
\hline & control & $(0.09)$ & $(0.08)$ & $(0.09)$ & $(0.03)$ & $(0.02)$ & $(0.00)$ \\
\hline & Psychological & 1.96 & 1.91 & 1.84 & 1.81 & 1.77 & 1.75 \\
\hline & control & $(0.27)$ & $(0.26)$ & $(0.24)$ & $(0.24)$ & $(0.25)$ & $(0.36)$ \\
\hline \multirow[t]{9}{*}{ Father } & Support & $\begin{array}{l}4.29 \\
(0.16)\end{array}$ & $\begin{array}{l}4.28 \\
(0.17)\end{array}$ & $\begin{array}{l}4.25 \\
(0.18)\end{array}$ & $\begin{array}{l}4.23 \\
(0.18)\end{array}$ & $\begin{array}{l}4.24 \\
(0.19)\end{array}$ & $\begin{array}{l}4.20 \\
(0.19)\end{array}$ \\
\hline & Proactive & 4.23 & 4.17 & 4.14 & 4.09 & 4.05 & 3.81 \\
\hline & control & $(0.28)$ & $(0.26)$ & $(0.25)$ & $(0.26)$ & $(0.29)$ & $(0.31)$ \\
\hline & Punitive & 3.02 & 2.93 & 2.84 & 2.74 & 2.48 & 2.14 \\
\hline & control & $(0.95)$ & $(0.79)$ & $(0.77)$ & $(0.86)$ & $(0.83)$ & $(0.67)$ \\
\hline & Harsh punitive & 1.11 & 1.06 & 1.07 & 1.05 & 1.03 & 1.03 \\
\hline & control & $(0.7)$ & $(0.05)$ & $(0.06)$ & $(0.03)$ & $(0.02)$ & $(0.01)$ \\
\hline & Psychological & 1.87 & 1.82 & 1.84 & 1.81 & 1.77 & 1.58 \\
\hline & control & $(0.26)$ & $(0.24)$ & $(0.27)$ & $(0.25)$ & $(0.24)$ & $(0.18)$ \\
\hline \multirow[t]{4}{*}{ Adolescent } & Rule breaking & 0.20 & 0.21 & 0.23 & 0.23 & 0.21 & 0.19 \\
\hline & behavior & $(0.03)$ & $(0.03)$ & $(0.03)$ & $(0.04)$ & $(0.03)$ & $(0.03)$ \\
\hline & Aggressive & 0.29 & 0.28 & 0.28 & 0.27 & 0.26 & 0.22 \\
\hline & behavior & $(0.06)$ & $(0.05)$ & $(0.05)$ & $(0.05)$ & $(0.04)$ & $(0.04)$ \\
\hline
\end{tabular}


Table 2a

LCGA Model Fit Criteria for Mother-Reported Parenting Dimensions

\begin{tabular}{|c|c|c|c|c|c|}
\hline & & \multicolumn{4}{|c|}{ Number of subclasses } \\
\hline Dimension & 1 & 2 & 3 & 4 & 5 \\
\hline \multicolumn{6}{|l|}{ Support } \\
\hline$\%$ & & 32 & 5 & 0 & 0 \\
\hline LMR & & $<.001$ & .075 & .500 & .914 \\
\hline BLRT & & $<.001$ & $<.001$ & & \\
\hline SS-BIC & 2092.678 & 1603.869 & 1457.796 & 1472.356 & 1403.508 \\
\hline Entropy & & .707 & .743 & .796 & .727 \\
\hline \multicolumn{6}{|c|}{ Proactive control } \\
\hline$\%$ & & 31 & 7 & 0.7 & 0.7 \\
\hline LMR & & $<.001$ & .066 & .001 & .290 \\
\hline BLRT & & $<.001$ & $<.001$ & & \\
\hline SS-BIC & 3107.063 & 2815.970 & 2751.060 & 2708.112 & 2702.614 \\
\hline Entropy & & .618 & .639 & .694 & .692 \\
\hline \multicolumn{6}{|c|}{ Punitive control } \\
\hline$\%$ & & 30 & 14 & 11 & 7 \\
\hline LMR & & $<.001$ & .027 & .002 & .394 \\
\hline BLRT & & $<.001$ & $<.001$ & $<.001$ & \\
\hline SS-BIC & 5653.783 & 5269.041 & 5180.883 & $\mathbf{5 1 5 8 . 5 3 5}$ & 5158.715 \\
\hline Entropy & & .667 & .619 & .598 & .604 \\
\hline \multicolumn{6}{|c|}{ Psychological control } \\
\hline$\%$ & & 23 & 9 & 3 & 0.5 \\
\hline LMR & & $<.001$ & .019 & .080 & .091 \\
\hline BLRT & & $<.001$ & $<.001$ & $<.001$ & \\
\hline SS-BIC & 3008.353 & 2541.682 & 2390.639 & 2335.524 & 2304.899 \\
\hline Entropy & & .752 & .691 & .694 & .735 \\
\hline \multicolumn{6}{|c|}{ Harsh punitive control } \\
\hline$\%$ & & 4 & 2 & 0.3 & 0.7 \\
\hline LMR & & .274 & .754 & .152 & .431 \\
\hline \multicolumn{6}{|l|}{ BLRT } \\
\hline SS-BIC & -687.742 & -1706.864 & -2454.819 & -2641.420 & -3072.777 \\
\hline Entropy & & .990 & .985 & .988 & .975 \\
\hline
\end{tabular}

Note. SS-BIC $=$ Sample Size adjusted Bayesian Information Criterion;

$\%=$ proportion of smallest subclass; LMR $=$ Lo-Mendell-Rubin test $p$-value;

BLRT $=$ bootstrap likelihood-ratio test.

The model in bold is the preferred model. 
Table 2b

LCGA Model Fit Criteria for Father-Reported Parenting Dimensions

\begin{tabular}{|c|c|c|c|c|c|}
\hline & & \multicolumn{4}{|c|}{ Number of subclasses } \\
\hline Dimension & 1 & 2 & 3 & 4 & 5 \\
\hline \multicolumn{6}{|l|}{ Support } \\
\hline$\%$ & & 25 & 3 & 1 & 0.8 \\
\hline LMR & & .008 & .140 & .124 & .676 \\
\hline BLRT & & $<.001$ & & & \\
\hline SS-BIC & 2862.817 & 2679.524 & 2601.122 & 2556.207 & 2540.891 \\
\hline Entropy & & .596 & 659 & .660 & .685 \\
\hline \multicolumn{6}{|c|}{ Proactive control } \\
\hline$\%$ & & 1 & 1 & 1 & 0.5 \\
\hline LMR & & .554 & .183 & .057 & .338 \\
\hline BLRT & & & & $<.001$ & \\
\hline SS-BIC & 2949.998 & 2907.543 & 2898.787 & 2890.025 & 2892.790 \\
\hline Entropy & & .927 & .867 & .748 & .741 \\
\hline \multicolumn{6}{|c|}{ Punitive control } \\
\hline$\%$ & & 32 & 15 & 1 & 1 \\
\hline LMR & & $<.001$ & .047 & .036 & .253 \\
\hline BLRT & & $<.001$ & $<.001$ & $<.001$ & \\
\hline SS-BIC & 5018.893 & 4835.874 & 4803.278 & 4792.938 & 4792.979 \\
\hline Entropy & & .552 & .531 & .595 & .582 \\
\hline \multicolumn{6}{|c|}{ Psychological control } \\
\hline$\%$ & & 20 & 9 & 3 & 2 \\
\hline LMR & & $<.001$ & .042 & .036 & .253 \\
\hline BLRT & & $<.001$ & $<.001$ & $<.001$ & \\
\hline SS-BIC & 2786.238 & 2618.335 & 2575.988 & 2551.047 & 2542.975 \\
\hline Entropy & & .654 & .563 & .622 & .635 \\
\hline \multicolumn{6}{|c|}{ Harsh punitive control } \\
\hline$\%$ & & 3 & 2 & 1 & 0.2 \\
\hline LRMT & & .106 & .754 & .282 & .200 \\
\hline \multicolumn{6}{|l|}{ BLRT } \\
\hline SS-BIC & -74.093 & -900.882 & -1363.058 & -1609.274 & -1724.760 \\
\hline Entropy & & .993 & .963 & .952 & .942 \\
\hline
\end{tabular}

Note. SS-BIC = Sample Size adjusted Bayesian Information Criterion;

$\%=$ proportion of smallest subclass; LMR = Lo-Mendell-Rubin test;

BLRT $=$ bootstrap likelihood-ratio test.

The model in bold is the preferred model. 
Table 3

Model Comparison of Unconditional Growth Models for Both Aggressive and Rule-Breaking

Behavior

\begin{tabular}{llllllll}
\hline Model & & $\chi^{2}$ & $d f$ & SCF & $\Delta \chi^{2}$ & $\Delta d f$ & $p$ \\
\hline Aggressive & Intercept & 63.416 & 12 & 1.4299 & & & \\
behavior & Intercept + linear trend & 23.314 & 9 & 1.4433 & 41.0372 & 3 & $<.001$ \\
& Intercept + linear trend + & 5.250 & 5 & 1.3417 & 16.9427 & 4 & .002 \\
& quadratic trend & & & & & & \\
& & & & & & & \\
Rule-breaking & Intercept & 63.371 & 12 & 1.3117 & & & \\
behavior & Intercept + linear trend & 34.723 & 9 & 1.3285 & 29.3302 & 3 & $<.001$ \\
& Intercept + linear trend + & 4.451 & 5 & 1.2856 & 29.2356 & 4 & $<.001$ \\
& quadratic term & & & & & & \\
\hline
\end{tabular}


Table $4 \mathrm{a}$

Results of the Conditional Growth Models of Aggressive and Rule-Breaking Behavior on the Trajectory Classes of Support



Note. $\mathrm{AB}=$ Aggressive behavior; $\mathrm{RBB}=$ Rule-breaking behavior. Gender coded as female $=1$ and male $=0$.

The respective reference group was indicated in bold. 
Table $4 \mathrm{~b}$

Results of the Conditional Growth Models of Aggressive and Rule-Breaking Behavior on the Trajectory Classes of Proactive Control

\begin{tabular}{|c|c|c|c|c|c|c|c|c|}
\hline $\begin{array}{l}\text { Outcome } \\
\text { (adolescent report) }\end{array}$ & $R^{2}(p)$ & $\begin{array}{l}\text { Proactive control } \\
\text { (mother report) }\end{array}$ & $\beta$ & $p$ & $R^{2}(p)$ & $\begin{array}{l}\text { Proactive control } \\
\text { (father report) }\end{array}$ & $\beta$ & $p$ \\
\hline Intercept $\mathrm{AB}$ & $\begin{array}{l}.003 \\
(.509)\end{array}$ & $\begin{array}{l}\text { Gender } \\
\text { Very high-stable } \\
\text { High stable } \\
\text { Moderate-stable }\end{array}$ & $\begin{array}{l}0.002 \\
0.010\end{array}$ & $\begin{array}{l}.957 \\
.860\end{array}$ & $\begin{array}{l}.006 \\
(.342)\end{array}$ & $\begin{array}{l}\text { Gender } \\
\text { Moderate-increasing } \\
\text { Low-increasing-inv. U-shape } \\
\text { Very high-stable } \\
\text { High-stable }\end{array}$ & $\begin{array}{l}-0.042 \\
0.009 \\
0.008\end{array}$ & $\begin{array}{l}.123 \\
.844 \\
.875\end{array}$ \\
\hline Linear trend $\mathrm{AB}$ & $\begin{array}{l}.007 \\
(.533)\end{array}$ & $\begin{array}{l}\text { Gender } \\
\text { Very high- stable } \\
\text { High stable } \\
\text { Moderate- stable }\end{array}$ & $\begin{array}{l}0.051 \\
0.002 \\
0.060\end{array}$ & $\begin{array}{l}.410 \\
.971 \\
.382\end{array}$ & $\begin{array}{l}.016 \\
(.268)\end{array}$ & $\begin{array}{l}\text { Gender } \\
\text { Moderate-increasing } \\
\text { Low-increasing-inv. U-shape } \\
\text { Very high-stable } \\
\text { High-stable }\end{array}$ & $\begin{array}{l}0.082 \\
.064 \\
-0.062 \\
-0.035\end{array}$ & $\begin{array}{l}.210 \\
.183 \\
.212 \\
.596\end{array}$ \\
\hline Intercept RBB & $\begin{array}{l}.111 \\
(.033)\end{array}$ & $\begin{array}{l}\text { Gender } \\
\text { Very high- stable } \\
\text { High stable } \\
\text { Moderate- stable }\end{array}$ & $\begin{array}{l}-0.230 \\
-0.200 \\
-0.095\end{array}$ & $\begin{array}{l}.001 \\
.002 \\
.092\end{array}$ & $\begin{array}{l}.095 \\
(.068)\end{array}$ & $\begin{array}{l}\text { Gender } \\
\text { Moderate-increasing } \\
\text { Low-increasing-inv. U-shape } \\
\text { Very high-stable } \\
\text { High-stable }\end{array}$ & $\begin{array}{l}-0.282 \\
0.059 \\
0.103 \\
-0.043\end{array}$ & $\begin{array}{l}<.001 \\
\\
.202 \\
.449 \\
.415\end{array}$ \\
\hline Linear trend RBB & $\begin{array}{l}.032 \\
(.271)\end{array}$ & $\begin{array}{l}\text { Gender } \\
\text { Very high- stable } \\
\text { High stable } \\
\text { Moderate- stable }\end{array}$ & $\begin{array}{l}-0.039 \\
-0.062 \\
0.159\end{array}$ & $\begin{array}{l}.577 \\
.370 \\
.048\end{array}$ & $\begin{array}{l}.004 \\
(.812)\end{array}$ & $\begin{array}{l}\text { Gender } \\
\text { Moderate-increasing } \\
\text { Low-increasing-inv. U-shape } \\
\text { Very high-stable } \\
\text { High-stable }\end{array}$ & $\begin{array}{l}-0.013 \\
-0.002 \\
-0.058 \\
0.008\end{array}$ & $\begin{array}{l}.862 \\
.982 \\
.661 \\
.922\end{array}$ \\
\hline Quadratic trend RBB & $\begin{array}{l}.021 \\
(.340)\end{array}$ & $\begin{array}{l}\text { Gender } \\
\text { Very high- stable } \\
\text { High stable } \\
\text { Moderate- stable }\end{array}$ & $\begin{array}{l}-0.026 \\
0.072 \\
-0.114\end{array}$ & $\begin{array}{l}.703 \\
.280 \\
.106\end{array}$ & $\begin{array}{l}.004 \\
(.690)\end{array}$ & $\begin{array}{l}\text { Gender } \\
\text { Moderate-increasing } \\
\text { Low-increasing-inv. U-shape } \\
\text { Very high-stable } \\
\text { High-stable }\end{array}$ & $\begin{array}{l}-0.044 \\
-0.013 \\
0.033 \\
0.040 \\
\end{array}$ & $\begin{array}{l}.516 \\
.842 \\
.742 \\
.631 \\
\end{array}$ \\
\hline
\end{tabular}

Note. $\mathrm{AB}=$ Aggressive behavior; $\mathrm{RBB}=$ Rule-breaking behavior. Gender coded as female $=1$ and male $=0$.

The respective reference group was indicated in bold. 
Table 4c

Results of the Conditional Growth Models of Aggressive and Rule-Breaking Behavior on the Trajectory Classes of Punitive Control

\begin{tabular}{|c|c|c|c|c|c|c|c|c|}
\hline $\begin{array}{l}\text { Outcome } \\
\text { (adolescent report) }\end{array}$ & $R^{2}(p)$ & $\begin{array}{l}\text { Punitive control } \\
\text { (mother report) }\end{array}$ & $\beta$ & $p$ & $R^{2}(p)$ & $\begin{array}{l}\text { Punitive control } \\
\text { (father report) }\end{array}$ & $\beta$ & $p$ \\
\hline Intercept $\mathrm{AB}$ & $\begin{array}{c}.026 \\
(.045)\end{array}$ & $\begin{array}{l}\text { Gender } \\
\text { Moderate high-decreasing } \\
\text { Low-stable } \\
\text { High-decreasing } \\
\text { Moderate low-decreasing }\end{array}$ & $\begin{array}{l}-0.037 \\
-0.119 \\
0.023 \\
-0.112\end{array}$ & $\begin{array}{l}.398 \\
.002 \\
.668 \\
.010\end{array}$ & $\begin{array}{c}.027 \\
(.078)\end{array}$ & $\begin{array}{l}\text { Gender } \\
\text { Moderate-decreasing } \\
\text { Low-stable } \\
\text { Moderate-increasing-U-shape } \\
\text { High-decreasing }\end{array}$ & $\begin{array}{l}-0.049 \\
-0.088 \\
-0.029 \\
0.104\end{array}$ & $\begin{array}{l}.041 \\
.273 \\
.051\end{array}$ \\
\hline Linear trend $A B$ & $\begin{array}{c}.018 \\
(.269)\end{array}$ & $\begin{array}{l}\text { Gender } \\
\text { Moderate high-decreasing } \\
\text { Low-stable } \\
\text { High-decreasing } \\
\text { Moderate low-decreasing }\end{array}$ & $\begin{array}{l}0.041 \\
0.084 \\
0.072 \\
0.114\end{array}$ & $\begin{array}{l}.506 \\
.121 \\
.322 \\
.079\end{array}$ & $\begin{array}{l}.022 \\
(.290)\end{array}$ & $\begin{array}{l}\text { Gender } \\
\text { Moderate-decreasing } \\
\text { Low-stable } \\
\text { Moderate- increasing -U-shape } \\
\text { High-decreasing }\end{array}$ & $\begin{array}{l}0.074 \\
0.060 \\
0.039 \\
-0.083\end{array}$ & $\begin{array}{l}.256 \\
.338 \\
.360 \\
.284\end{array}$ \\
\hline Intercept RBB & $\begin{array}{l}.125 \\
(.036)\end{array}$ & $\begin{array}{l}\text { Gender } \\
\text { Moderate high-decreasing } \\
\text { Low-stable } \\
\text { High-decreasing } \\
\text { Moderate low-decreasing }\end{array}$ & $\begin{array}{l}-0.207 \\
-0.194 \\
0.048 \\
-0.192\end{array}$ & $\begin{array}{l}.003 \\
.001 \\
.556 \\
.004\end{array}$ & $\begin{array}{l}.141 \\
(.034)\end{array}$ & $\begin{array}{l}\text { Gender } \\
\text { Moderate-decreasing } \\
\text { Low-stable } \\
\text { Moderate- increasing - U -shape } \\
\text { High-decreasing }\end{array}$ & $\begin{array}{l}-0.280 \\
-0.093 \\
-0.019 \\
0.187\end{array}$ & $\begin{array}{l}.114 \\
.757 \\
.031\end{array}$ \\
\hline Linear trend RBB & $\begin{array}{l}.012 \\
(.398)\end{array}$ & $\begin{array}{l}\text { Gender } \\
\text { Moderate high-decreasing } \\
\text { Low-stable } \\
\text { High-decreasing } \\
\text { Moderate low-decreasing }\end{array}$ & $\begin{array}{l}-0.055 \\
0.089 \\
-0.032 \\
0.042\end{array}$ & $\begin{array}{l}.428 \\
.192 \\
.699 \\
.560\end{array}$ & $\begin{array}{l}.021 \\
(.423)\end{array}$ & $\begin{array}{l}\text { Gender } \\
\text { Moderate-decreasing } \\
\text { Low-stable } \\
\text { Moderate- increasing - U -shape } \\
\text { High-decreasing }\end{array}$ & $\begin{array}{l}-0.014 \\
0.081 \\
0.038 \\
-0.095\end{array}$ & $\begin{array}{l}.860 \\
.292 \\
.639 \\
.295\end{array}$ \\
\hline Quadratic trend RBB & $\begin{array}{l}.010 \\
(.484)\end{array}$ & $\begin{array}{l}\text { Gender } \\
\text { Moderate high-decreasing } \\
\text { Low-stable } \\
\text { High-decreasing } \\
\text { Moderate low-decreasing }\end{array}$ & $\begin{array}{l}-0.013 \\
-0.090 \\
0.032 \\
0.001\end{array}$ & $\begin{array}{l}.847 \\
.200 \\
.660 \\
.994\end{array}$ & $\begin{array}{l}.020 \\
(.401)\end{array}$ & $\begin{array}{l}\text { Gender } \\
\text { Moderate-decreasing } \\
\text { Low-stable } \\
\text { Moderate- increasing - U -shape } \\
\text { High-decreasing }\end{array}$ & $\begin{array}{l}-0.118 \\
-0.014 \\
0.036\end{array}$ & $\begin{array}{l}.562 \\
.126 \\
.834 \\
.639\end{array}$ \\
\hline
\end{tabular}

Note. $\mathrm{AB}=$ Aggressive behavior; $\mathrm{RBB}=$ Rule-breaking behavior. Gender coded as female $=1$ and male $=0$. 
Table 4d

Results of the Conditional Growth Models of Aggressive and Rule-Breaking Behavior on the Trajectory Classes of Psychological Control

\begin{tabular}{|c|c|c|c|c|c|c|c|c|}
\hline $\begin{array}{l}\text { Outcome } \\
\text { (adolescent report) }\end{array}$ & $R^{2}(p)$ & $\begin{array}{l}\text { Psychological control } \\
\text { (mother report) }\end{array}$ & $\beta$ & $p$ & $R^{2}(p)$ & $\begin{array}{l}\text { Psychological control } \\
\text { (father report) }\end{array}$ & $\beta$ & $p$ \\
\hline \multirow[t]{4}{*}{ Intercept $\mathrm{AB}$} & $\begin{array}{l}.059 \\
(.013)\end{array}$ & $\begin{array}{l}\text { Gender } \\
\text { Moderate low-stable }\end{array}$ & -0.041 & .352 & \multirow[t]{4}{*}{$\begin{array}{l}.058 \\
(.001)\end{array}$} & $\begin{array}{l}\text { Gender } \\
\text { Low-stable }\end{array}$ & -0.044 & .335 \\
\hline & & Moderate-stable & -0.088 & .043 & & Moderate low-stable & 0.184 & $<.001$ \\
\hline & & Moderate high-decreasing & 0.099 & .090 & & Moderate high-U-shape & 0.099 & .083 \\
\hline & & Low-stable & 0.172 & .002 & & Moderate high- inv. U-shape & 0.173 & .005 \\
\hline \multirow[t]{5}{*}{ Linear trend $\mathrm{AB}$} & .009 & Gender & 0.049 & .429 & \multirow{5}{*}{$\begin{array}{c}.020 \\
(.323)\end{array}$} & Gender & 0.076 & .247 \\
\hline & $(.500)$ & Moderate low-stable & & & & Low-stable & & \\
\hline & & Moderate-stable & 0.021 & .739 & & Moderate low-stable & 0.006 & .928 \\
\hline & & Moderate high-decreasing & 0.046 & .562 & & Moderate high-U-shape & -0.014 & .868 \\
\hline & & Low-stable & -0.055 & .482 & & Moderate high- inv. U-shape & -0.117 & .129 \\
\hline \multirow[t]{5}{*}{ Intercept RBB } & .119 & Gender & -0.223 & .001 & \multirow{5}{*}{$\begin{array}{l}.139 \\
(.036)\end{array}$} & Gender & -0.280 & $<.001$ \\
\hline & & Moderate low-stable & & & & Low-stable & & \\
\hline & & Moderate-stable & -0.188 & .010 & & Moderate low-stable & 0.134 & .051 \\
\hline & & Moderate high-decreasing & 0.021 & .801 & & Moderate high- U -shape & 0.119 & .060 \\
\hline & & Low-stable & 0.101 & .163 & & Moderate high -inv. U-shape & 0.186 & .027 \\
\hline \multirow[t]{5}{*}{ Linear trend RBB } & .041 & Gender & -0.049 & .479 & \multirow{5}{*}{$\begin{array}{c}.001 \\
(.832)\end{array}$} & Gender & 0.002 & .979 \\
\hline & $(.283)$ & Moderate low-stable & & & & Low-stable & & \\
\hline & & Moderate-stable & 0.117 & .143 & & Moderate low-stable & 0.025 & .734 \\
\hline & & Moderate high-decreasing & 0.165 & .098 & & Moderate high- U -shape & -0.020 & .824 \\
\hline & & Low-stable & -0.034 & .665 & & Moderate high- inv. U-shape & 0.001 & .992 \\
\hline \multirow[t]{5}{*}{ Quadratic trend RBB } & .041 & Gender & -0.014 & .840 & \multirow{5}{*}{$\begin{array}{c}.004 \\
(.710)\end{array}$} & Gender & -0.053 & .450 \\
\hline & $(.286)$ & Moderate low-stable & & & & Low-stable & & \\
\hline & & Moderate-stable & -0.098 & .193 & & Moderate low-stable & -0.011 & .860 \\
\hline & & Moderate high-decreasing & -0.141 & .112 & & Moderate high- U -shape & 0.018 & .860 \\
\hline & & Low-stable & 0.085 & .317 & & Moderate high- inv. U-shape & -0.017 & .836 \\
\hline
\end{tabular}

Note. $\mathrm{AB}=$ Aggressive behavior; $\mathrm{RBB}=$ Rule-breaking behavior. Gender coded as female $=1$ and male $=0$ 


\section{Appendices}

\section{Appendix 1: Youth Self Report (YSR)}

1. Ik drink alcohol zonder dat mijn ouders dat goed vinden.

2. Ik maak veel ruzie.

3. Ik ben gemeen tegen anderen.

4. Ik probeer veel aandacht te krijgen.

5. Ik verniel mijn eigen spullen.

6. Ik verniel de spullen van anderen.

7. Ik gehoorzaam mijn ouders niet.

8. Ik ben ongehoorzaam op school.

9. Ik voel me niet schuldig als ik iets gedaan heb wat ik niet had moeten doen.

10. Ik hou me niet aan de regels thuis, op school of ergens anders.

11. Ik vecht veel.

12. Ik ga om met jongens en meisjes die in moeilijkheden raken.

13. Ik lieg of bedrieg.

14. Ik val mensen lichamelijk aan.

15. Ik ga liever om met oudere jongens of meisjes dan met jongens en meisjes van mijn eigen leeftijd.

16. Ik loop van huis weg.

17. Ik schreeuw veel.

18. Ik sticht brandjes.

19. Ik steel thuis.

20. Ik steel buitenshuis

21. Ik ben koppig.

22. Mijn stemming of gevoelens veranderen plotseling.

23. Ik ben achterdochtig.

24. Ik vloek of gebruik vieze woorden.

25. Ik pest anderen veel.

26. Ik ben snel driftig.

27. Ik denk te veel aan seks.

28. Ik dreig mensen om hen pijn te doen.

29. Ik sla lessen over of spijbel van school.

30. Ik ben luidruchtiger dan andere jongens of meisjes.

31. Ik gebruik drugs. 


\section{Appendix 2: Parenting Practices}

1. Als mijn kind mij iets wil vertellen, maak ik tijd om er naar te luisteren.

2. Als mijn kind zich niet aan een afspraak gehouden heeft (bijvoorbeeld: te laat thuis komen zonder geldige reden, een taak niet uitvoeren), dan geef ik hem/haar een straf.

3. Ik leer mijn kind om beleefd te zijn op school.

4. Ik geef mijn kind een klap als hij/zij iets gedaan heeft dat niet mag.

5. Als mijn kind een probleem lijkt te hebben, bespreek ik samen met hem/haar wat er juist aan de hand is.

6. Als mijn kind tegenspreekt, liegt of ruzie maakt, laat ik daar een straf op volgen.

7. Ik geef mijn kind een pak rammel als hij/zij ongehoorzaam is.

8. Ik leer mijn kind om zich aan afspraken te houden.

9. Als mijn kind een probleem heeft, bekijk ik samen met hem/haar welke verschillende oplossingen er mogelijk zijn.

10. Als mijn kind iets gedaan heeft wat niet mag, straf ik hem/haar door iets leuks te ontnemen (bijvoorbeeld: geen TV kijken, huisarrest).

11. Ik vraag naar de hobby's en interesses van mijn kind.

12. Ik schud mijn kind eens goed door elkaar als we een ruzie hebben.

13. Als ik mijn kind terugzie na zijn/haar schooldag maak ik tijd om even met hem/haar bezig te zijn.

14. Ik geef mijn kind voor goed gedrag als beloning een complimentje, een knuffel of een schouderklopje.

15. Ik geef mijn kind een slag in het gezicht als hij/zij zich misdraagt.

16. Ik leer mijn kind om zich aan te passen aan de regels op school.

17. Als mijn kind en ik een meningsverschil hebben, praat ik dat uit en zoek ik een oplossing, samen met mijn kind.

18. Als mijn kind iets doet dat niet mag, geef ik hem/haar straf.

19. Ik doe activiteiten samen met mijn kind, omdat ik weet dat mijn kind die activiteit graag samen met mij doet (bijvoorbeeld: een gezelschapsspel spelen, samen winkelen, ...).

20. Ik geef mijn kind een pak slaag als hij/zij zich niet aan een afspraak heeft gehouden.

21. Ik spreek met mijn kind af fatsoenlijk om te gaan met zijn/haar spullen.

22. Ik maak met mijn kind afspraken over hoe hij/zij zich moet gedragen.

23. Ik zorg dat mijn zoon of dochter zich beter voelt als hij zijn of haar zorgen met mij heeft besproken.

24. Ik heb duidelijke verwachtingen over hoe mijn zoon of dochter zich thuis en buitenshuis dient te gedragen.

25. Ik stel mijn zoon of dochter vragen over hoe hij of zij zich buitenshuis gedraagt.

26. Ik probeer de manier waarop mijn zoon of dochter de dingen ziet te veranderen.

27. Ik ontplof in woede tegen mijn zoon of dochter.

28. Ik geef mijn zoon of dochter inspraak in beslissingen. 
29. Ik glimlach vaak naar mijn zoon of dochter.

30. Ik verwacht dat mijn zoon of dochter zich op een bepaalde manier gedraagt.

31. Ik herinner mijn zoon of dochter aan de regels die ik voor hem of haar heb opgesteld.

32. Ik verander van gespreksonderwerp wanneer mijn zoon of dochter iets te vertellen heeft.

33. Ik werp een boze blik naar mijn zoon of dochter.

34. Ik laat mijn zoon of dochter toe om mee te beslissen.

35. Ik kan ervoor zorgen dat mijn zoon of dochter zich beter voelt als hij of zij van streek is.

36. Ik vind dat kinderen niet zomaar alles mogen doen wat ze willen.

37. Ik zie erop toe dat mijn zoon of dochter zich gedraagt zoals het hoort.

38. Ik onderbreek mijn zoon of dochter wanneer hij/zij iets vertelt.

39. Ik roep en tier wanneer mijn zoon of dochter zich slecht gedraagt.

40. Ik vrolijk mijn zoon of dochter op als hij/zij droevig is.

41. Ik wil dat mijn zoon of dochter leert om bepaalde regels na te volgen, zowel thuis als buitenshuis.

42. Ik praat over het gedrag van mijn zoon of dochter met buren, andere ouders of met zijn of haar leraren.

43. Ik geef mijn zoon of dochter de schuld van de problemen van andere gezinsleden.

44. Ik maak ruzie met mijn zoon of dochter.

45. Ik geef mijn zoon/dochter veel zorg en aandacht.

46. Ik vind dat ouders het recht hebben om regels te bepalen waarnaar kinderen zich dienen te gedragen.

47. Ik doe moeite om te weten te komen wie de vrienden van mijn zoon of dochter zijn en waar hij of zij tijd doorbrengt.

48. Ik rakel de vroegere fouten van mijn zoon of dochter op wanneer ik hem of haar bekritiseer.

49. Ik toon me geërgerd door het gedrag van mijn zoon of dochter.

50. Ik houd rekening met de mening van mijn zoon of dochter over zaken die hem/haar aanbelangen.

51. Ik vind het belangrijk om mijn zoon of dochter te tonen dat ik van hem of haar houd.

52. Ik ben minder vriendelijk tegen mijn zoon of dochter wanneer hij of zij de dingen niet op mijn manier ziet.

53. Ik zeg gemene dingen tegen mijn zoon of dochter.

54. Ik vind de mening van mijn zoon of dochter belangrijk.

55. Ik doe graag dingen samen met mijn zoon of dochter.

56. Ik heb redelijke verwachtingen over het gedrag van mijn zoon of dochter.

57. Ik vermijd mijn zoon of dochter aan te kijken wanneer hij/zij mij heeft teleurgesteld.

58. Ik help mijn zoon of dochter zijn/haar eigen weg te kiezen.

59. Ik ga op een redelijke manier na of mijn zoon of dochter zich gedraagt zoals ik dat wil.

60. Ik praat niet meer met mijn zoon of dochter als hij/zij mij heeft ontgoocheld, tot hij/zij me weer plezier doet. 
61. Ik maak dat mijn zoon of dochter zich schuldig voelt als hij/zij iets niet goed heeft gedaan.

62. Ik leg mijn zoon of dochter uit waarom hij of zij bepaalde zaken moet doen.

63. Als mijn zoon of dochter iets moet doen, dan leg ik hem/haar uit waarom dat belangrijk is.

64. Ik geef mijn zoon of dochter keuze in hoe hij of zij de zaken aanpakt. 